\title{
T-cell Responses in the Microenvironment of Primary Renal Cell Carcinoma- Implications for Adoptive Cell Therapy
}

Andersen, Rikke; Westergaard, Marie Christine Wulff; Kjeldsen, Julie Westerlin; Mueller, Anja; Pedersen, Natasja Wulff; Hadrup, Sine Reker; Met, Ozcan; Seliger, Barbara; Kromann-Andersen, Bjarne;

Hasselager, Thomas

Total number of authors:

12

Published in:

Cancer Immunology Research

Link to article, DOI:

10.1158/2326-6066.CIR-17-0467

Publication date:

2018

Document Version

Peer reviewed version

Link back to DTU Orbit

Citation $(A P A)$ :

Andersen, R., Westergaard, M. C. W., Kjeldsen, J. W., Mueller, A., Pedersen, N. W., Hadrup, S. R., Met, O., Seliger, B., Kromann-Andersen, B., Hasselager, T., Donia, M., \& Svane, I. M. (2018). T-cell Responses in the Microenvironment of Primary Renal Cell Carcinoma-Implications for Adoptive Cell Therapy. Cancer Immunology Research, 6(2), 222-235. https://doi.org/10.1158/2326-6066.CIR-17-0467

\section{General rights}

Copyright and moral rights for the publications made accessible in the public portal are retained by the authors and/or other copyright owners and it is a condition of accessing publications that users recognise and abide by the legal requirements associated with these rights.

- Users may download and print one copy of any publication from the public portal for the purpose of private study or research.

- You may not further distribute the material or use it for any profit-making activity or commercial gain

- You may freely distribute the URL identifying the publication in the public portal 
Title: T-cell responses in the microenvironment of primary renal cell carcinoma - Implications for adoptive cell therapy

Authors: Rikke Andersen ${ }^{1,2}$, Marie Christine Wulff Westergaard ${ }^{1}$, Julie Westerlin Kjeldsen ${ }^{1}$, Anja Müller $^{3}$, Natasja Wulff Pedersen ${ }^{4}$, Sine Reker Hadrup ${ }^{4}$, Özcan Met $^{1,2}$, Barbara Seliger ${ }^{3}$, Bjarne Kromann-Andersen ${ }^{5}$, Thomas Hasselager ${ }^{6}$, Marco Donia ${ }^{1,2,}$, Inge Marie Svane ${ }^{1,2, \S}$.

\section{Affiliations:}

${ }^{1}$ Center for Cancer Immune Therapy, Department of Hematology, Herlev Hospital, University of Copenhagen, Herlev, Denmark

${ }^{2}$ Department of Oncology, Herlev Hospital, University of Copenhagen, Herlev, Denmark

${ }^{3}$ Institute of Medical Immunology, Martin Luther University Halle-Wittenberg, Halle, Germany.

${ }^{4}$ Division for Immunology and Vaccinology, Technical University of Denmark.

${ }^{5}$ Department of Urology, Herlev Hospital, University of Copenhagen, Herlev, Denmark

${ }^{6}$ Department of Pathology, Herlev Hospital, University of Copenhagen, Herlev, Denmark.

${ }^{\S}$ These authors contributed equally to this work.

Running Title: T-cell responses in primary RCC - Implications for ACT 
Summary (limit 38 words): TILs isolated from primary RCC specimens could recognize tumors. However, their immune responses were weaker than MM-TILs and displayed a mono-/oligo- functional pattern. The ability to select and expand poly-functional T cells may improve cell therapy for RCC.

Keywords: Tumor-infiltrating lymphocytes, cytotoxic T cells, renal cell carcinoma, metastatic melanoma, adoptive cell therapy

\section{Corresponding Authors:}

Inge Marie Svane, Email: inge.marie.svane@ regionh.dk, phone: +4538689339 , fax: +4538683457 and Marco Donia, Email: marco.donia@ regionh.dk, phone: +4538681456, fax: +4538683457, Center for Cancer Immune Therapy, Department of Hematology and Department of Oncology, Herlev Hospital, University of Copenhagen, Denmark.

Conflicts of Interest Disclosure: The authors declare no conflicts of interest

Word count: 5559 
Financial support: The Research Council at Herlev Hospital, The Danish Cancer Society, and The

Danish Cancer Research Foundation as well as the Mildred Scheel Stiftung (BS) grant 110703 and 111091.

Total number of Figures and Tables: 4 figures, 4 supplementary tables and 16 supplementary figures

\begin{abstract}
In vitro expansion of large numbers of highly potent tumor-reactive T cells appears a prerequisite for effective adoptive cell therapy (ACT) with autologous tumor-infiltrating lymphocytes (TIL) as shown in metastatic melanoma (MM). We therefore sought to determine whether renal cell carcinomas (RCC) are infiltrated with tumor-reactive T cells that could be efficiently employed for adoptive transfer immunotherapy. TILs and autologous tumor cell lines (TCLs) were successfully generated from 22 (92\%) and $17(77 \%)$ of 24 consecutive primary RCC specimens and compared to those generated from MM. Immune recognition of autologous TCLs or fresh tumor digests (FTD) was observed in CD8 ${ }^{+}$ TILs from $82 \%$ of patients (18/22). Cytotoxicity assays confirmed the tumoricidal capacity of RCCTILs. The overall expansion capacity of RCC-TILs was similar to MM-TILs. However, the magnitude, poly-functionality, and ability to expand in classical expansion protocols of $\mathrm{CD}^{+} \mathrm{T}$-cell responses was lower compared to MM-TILs. The RCC-TILs that did react to the tumor were functional and antigen presentation and processing of RCC-tumors was similar to MM-TILs. Direct recognition of tumors with cytokine-induced overexpression of human leukocyte antigen (HLA) class II was observed from $\mathrm{CD}^{+} \mathrm{T}$ cells $(6 / 12 ; 50 \%)$. Thus, TILs from primary RCC specimens could be isolated, expanded, and could recognize tumors. However, immune responses of expanded CD ${ }^{+}$RCC-TILs were typically
\end{abstract}


weaker than MM-TILs and displayed a mono-/oligo- functional pattern. The ability to select, enrich, and expand tumor-reactive poly-functional T cells may be critical in developing effective ACT with TILs for RCC.

\section{Main Text}

\section{Introduction}

Adoptive cell therapy (ACT) based on the infusion of expanded autologous tumor-infiltrating lymphocytes (TIL) has demonstrated durable complete tumor regressions in metastatic melanoma (MM) (1-7). TIL therapy relies on the infusion of potent TILs. In recent years, optimal phenotype, differentiation and homing characteristics of TILs to achieve durable cancer regression were described (8). Nevertheless, the ability to recognize autologous tumor cells through their T-cell receptor (TCR) represents the essential characteristic of effective TILs.

Whereas tumor-reactive TILs can be generated from the majority of MM-specimens $(9,10)$, the success rate appears lower for other cancers $(11-15)$. Results from two recent studies $(11,13)$ indicated that the tumor microenvironment (TME) of renal cell carcinoma (RCC) harbors tumor-reactive T cells, but how the magnitude and functional quality of these immune responses compare to other tumor types is unknown. Previous clinical trials investigating TIL therapy for RCC have shown modest success (16), however none of these early trials used current TIL-expansion methods and preparative chemotherapy 
regimens, opening the possibility to revisit TIL therapy for RCC. Consistent durable objective responses achieved in small numbers of patients treated with cytokine-based immunotherapy (17) or checkpoint inhibitors (18) demonstrates that immunological control of RCC can be feasible.

These observations prompted us $(i)$ to characterize the immune responses of TILs generated from primary RCC tumors (RCC) from 24 patients, and (ii) to compare RCC-TILs to MM-TILs. T-cell responses were detected in the majority of RCC analyzed. Extensive characterization of TILs revealed a unique functional pattern, with weaker and mostly mono- or oligo-functional CD ${ }^{+} \mathrm{T}$-cell responses compared to MM. These findings have relevance for the development of ACT for patients with RCC.

\section{Materials and methods}

\section{Patients and samples}

24 patients with histologically confirmed RCC, undergoing radical or partial nephrectomy at the Department of Urology, Herlev Hospital in the period from October 2013 to November 2015, were enrolled in the study. The study was approved by the Ethics Committee of the Capital region of Denmark and the Danish Data Protection Agency. All patients signed a written consent form. Tumor specimens of at least $1 \mathrm{~cm}^{3}$ were obtained from different sites of the primary RCC tumor in order to account for intra-tumor heterogeneity (19). Blood samples were collected prior to surgery; peripheral blood mononuclear cells (PBMCs) were isolated with standard methods and cryopreserved at -140 degrees until use. 
Treatment with autologous TILs resulted in high rates of tumor regression in MM (1). To compare the phenotype and functionality of RCC-TILs to a reference tumor histology, we used TILs and matched autologous tumor cell lines (TCL) derived from tumor specimens of patients with American Joint Committee on Cancer (AJCC) stage IV melanoma enrolled in one of the following clinical trials (ClinicalTrials.gov Identifier: NCT00937625 (20); NCT02278887, recruiting; NCT02379195, recruiting). TILs and TCLs from MM were established and analyzed in parallel to RCC specimens. Due to the limited availability of TILs from MM (most were typically used for clinical application), most MM-TIL samples could not be used for all comparison analyses with RCC-TILs. Rather, different individual MM-TILs were randomly selected for single comparison analyses. All analyses were performed once for each patient. One additional cohort of RCC-TIL $(n=6)$ obtained from primary clear cell RCC tumors from the University of Halle, Germany was shipped to Herlev Hospital and cultured as described below and used for additional phenotypic characterization analyses (expression of PD-1, LAG-3, TIM-3 and CD57), as described below.

\section{Generation of Young-TIL cultures}

Freshly resected tumor specimens were immediately transported to the laboratory in RPMI 1640 (Thermo Fisher Scientific, Waltham, MA, USA)-based transport media, and cut into 1-3 $\mathrm{mm}^{3}$ fragments that were used for generation of TIL, fresh tumor digests (FTD) or TCL. 48 tumor fragments were used for TIL generation and placed in individual wells of 24 well-culture plates (Nunc, Roskilde, Denmark) with $2 \mathrm{ml}$ complete medium (CM) consisting of 90\% RPMI 1640 (Thermo Fisher), 10\% heat inactivated AB Human serum (HS; Sigma-Aldrich), 6000 IU/ml IL-2 (Proleukin, Novartis, Basel, 
Switzerland), penicillin/streptomycin and fungizone (Bristol-Myers Squibb, Virum, Denmark) as previously described (21). The plates were placed in a humidified $37^{\circ} \mathrm{C}$ incubator with $5 \% \mathrm{CO}_{2}$. Half of the medium was replaced at day 5 and thereafter three times per week. TIL cultures were expanded in vitro directly from the tumor fragments according to the "minimally expanded" or "Young-TIL method", by pooling TIL micro-cultures derived from separate tumor fragments, as described previously (21). Young-TIL (Y-TIL) cultures were considered established if one pooled bulk TIL culture of $>100 \times 10^{6}$ cells was obtained within 60 days from surgery.

\section{Rapid expansion protocol (REP)}

To further test the expansion capacity of Y-TILs for clinical application, massive expansion in a standard 14 days rapid expansion protocol (REP) was performed on cryopreserved or freshly generated Y-TILs. REPs were performed in duplicates and in smaller scale than for patient treatment (test-REPs), but otherwise exactly as for clinical application, as previously described (21). Y-TILs were thawed and rested in CM for 2 days prior to initiating the REP. 1 x $10^{5}$ Y-TILs (in duplicates) were expanded in a small-scale REP using 30 ng/mL anti-CD3 antibodies (OKT3, from Janssen-Cilag or Miltenyi Biotec), irradiated (40 Gy) allogeneic feeder cells (peripheral blood mononuclear cells (PBMC) from at least three different healthy donors) in a ratio of 1:200 in medium containing $6000 \mathrm{IU} / \mathrm{ml} \mathrm{IL}-2$. The cells were incubated upright in $25 \mathrm{~cm}^{2}$ tissue culture flasks at $37^{\circ} \mathrm{C}$ in $5 \% \mathrm{CO}_{2}(21)$. Cell concentration was determined on day 7, 9, 12 and 14 and cells were split into larger flasks and additional media added as needed to maintain cell densities around 1-2 x 10 cells pr. ml. The cells were harvested on day 14 and fold expansion calculated. Y-TILs expanded in the REP are referred to as REP-TIL in this manuscript. 
REPs in very small scale (Mini-REPs) with alternative cytokine combinations were performed in single wells in a 96 well plates. Briefly, 5 x $10^{3}$ Y-TILs (in duplicates) were rapidly expanded as described above, using IL-2 alone (6000 IU/ml) or different combinations of IL-2 (6000 IU/ml), IL-7 (100 ng/ml), IL-15 (100 ng/ml) and IL-21 (100 ng/ml). Cytokines were added on day 0 and every time medium was replaced (on day 5 and thereafter approximately every other day). RCC-Y-TILs used were elected for their high reactivity but low or absent reactivity after classical REP. The six RCC-Y-TILs used were RCC4, RCC6, RCC12, RCC19, RCC23 and RCC26. One initial screening of seven different cytokine combinations was made in three RCC-Y-TILs. The following cytokine cocktails were used: IL-2; IL-15+IL-2; IL-7+IL-15+IL-21; IL-2+IL-21; IL-2+IL-7+IL-21; IL-2+IL-7; IL-15+IL-21. We next performed mini-REPs in three additional patients with only the three cytokine combinations where we detected responses after REP in the first screening: IL-2 alone, IL-7+IL-15+IL-21 and IL-15+IL-21.

\section{Autologous fresh tumor digests (FTDs) and tumor cell lines (TCLs)}

Single-cell suspensions were obtained from tumor fragments after overnight digestion. Briefly, after overnight incubation with enzyme cocktails (containing $1 \mathrm{mg} / \mathrm{ml}$ collagenase type IV, Sigma-Aldrich, and $0.0125 \mathrm{mg} / \mathrm{ml}$ dornase alpha, Pulmozyme, Roche), the obtained single-cell suspension were passed through $70-\mu \mathrm{m}$ strainers and immediately cryopreserved. The cellular composition of the resulting single-cell suspensions, which contained uncultured tumor cells and was named fresh tumor digests (FTDs), was not further analyzed. For analysis of TIL reactivity against FTDs, the single-cell suspensions were thawed and used immediately after a trypan blue viability count. 
Autologous short-term (<10 in vitro passages) cultured RCC and MM TCLs were generated from fresh tumor fragments or from cells recovered from the transport media, as previously described (10). Briefly, TCLs were established using standard splitting methods of cancer-like growing adherent cells in R10 media (containing RPMI 1640 with $10 \%$ fetal bovine serum (FBS) supplemented with 500 ng/ml Solu-Cortef). All autologous TCLs were established at our laboratory, and initially identified from their morphology and in vitro growth patterns. Additional validation of RCC-TCLs was carried out following cytospin centrifugation of freshly detached RCC cell lines. A combination of morphologic evaluation (according to standard cytologic criteria of malignancy (22) and immunohistochemistry (IHC) staining of Formalin-Fixed, Paraffin-Embedded (FFPE) tissue for various RCC markers was used. Supplementary Fig. S1 shows a representative image from a representative patient (RCC12). In a few cases, where the morphology or growth pattern of MM-TCLs was not typical of adherent tumor cell lines, the melanocyte-lineage was confirmed with PCR for melanocyte antigens, as previously described (10). TCLs were not otherwise authenticated or tested for Mycoplasma infection. The in vitro growth of RCC-TCLs was not always sufficient to carry out all experiments described below, but in all cases these experiments were conducted with at least 12 out of 17 RCCTCLs generated in this study.

\section{Flow Cytometry: antibodies and stainings}

For phenotype analysis of in vitro expanded TILs, the cells were stained at $4^{\circ} \mathrm{C}$ for 30 min in phosphate buffered saline (PBS, Lonza, Basel, Switzerland), washed and re-suspended in PBS and immediately analyzed. The following antibodies were used: CD3-AmCyan, CD4-PerCP, CD45RO-PE, CD45RA- 
APC, CD57-FITC, CD27-PE, CD62L-APCCy7, CD56-PeCy7, CD56-PE (all from BD Bioscience, Brøndby, Denmark), CD8-PB (Dako, Glostrup, Denmark), CCR7-FITC (R\&D Systems, Minneapolis, MN, USA), CD28-APC (Beckman Coulter, Brea, CA, USA). 7-aminoactinomycin D (7-AAD, BD) was added as control in a separate tube, to evaluate the amount of dead cells. At least 50000 TILs were acquired with a FACS Canto II (BD).

For functional characterization and phenotype analysis of tumor-reactive cells, the following antibodies were used: CD3-FITC, CD4-PerCP or CD4-Qdot705 (Thermo Fisher), CD8-Qdot605 (Thermo Fisher), CD107a-Brilliant Violet 421, (tumor necrosis factor) TNF-APC, (interferon-gamma) IFN $\gamma$-PeCy7, PD1-PE (eBiosciences, San Diego, CA, USA), LAG-3-FITC (Thermo Fisher), TIM-3-Qdot 655 and CD57-PECF594. The Live/Dead Fixable Near-IR Dead Cell Stain (Thermo Fisher) was used to discriminate dead cells. Where not indicated, antibodies were obtained from BD Biosciences (Brøndby, Denmark).

\section{Functional characterization of TILs}

In vitro expanded TILs and/or PBMCs were tested for reactivity against autologous short-term cultured TCLs (TILs and PBMCs) or autologous FTDs (only TILs) in co-culture assays as previously described $(23,24)$. In vitro expanded TILs and/or PBMCs were tested for reactivity against autologous short-term cultured TCLs (TILs and PBMCs) or autologous FTDs (only TILs) in co-culture assays, as previously described $(10,20)$. Briefly, TILs and PBMCs were thawed and rested overnight in RPMI $1640+10 \%$ HS, thereafter washed twice and co-cultured for 5 hours at $37^{\circ} \mathrm{C}$ with $5 \% \mathrm{CO}^{2}$ in the air with autologous FTDs (thawed and washed twice) or autologous short-term cultured TCL, pre-treated with 
$100 \mathrm{IU} / \mathrm{ml}$ (IFN $\gamma$ ) (Imukin, Boehringer-Ingelheim) for 72 hours or left untreated at an effector/target $(\mathrm{E} / \mathrm{T})$ ratio of 3:1 to 6:1. Anti-CD107a antibodies and GolgiPlug (BD, dilution of 1:1000) were added at the beginning of the incubation. Parallel cultures without cancer cells served as unstimulated control. Positive control wells were set up with the addition of Staphylococcus Enterotoxin B (SEB 5 $\mathrm{gg} / \mathrm{ml}$, Sigma-Aldrich, Brøndby, Denmark) in selected experiments. After five hours, the cells were washed twice with PBS and stained with antibodies directed to surface markers and live/dead reagents. Cells were washed one more time, fixed overnight, permeabilized (using the Foxp3/Transcription Factor Staining Buffer set, eBiosciences) and subsequently stained with antibodies for intracellular cytokines. In selected experiments, a functional analysis was combined with phenotype markers to assess the differentiation and dysfunctional state of tumor-reactive TILs. Since IFN $\gamma$ production was not observed frequently in RCC-TILs (see results), and we generally observed quite high TNF production in unstimulated samples (TILs without tumor), in these experiments we gated on $\mathrm{CD}^{+} \mathrm{CD} 107 \mathrm{a}^{+}$tumorreactive T cells to analyze the phenotype of tumor-reactive TILs. On the basis of these observations, CD107a upregulation might be indeed a more reliable marker for $\mathrm{T}$ cell reactivity to RCC especially in TIL populations with small responses. At least 50000 (basic functional characterization) or 500000 live TILs (phenotype of tumor-reactive TILs) were acquired respectively with a BD FACS Canto II or a BD LSRII.

Tumor reactivity was evaluated by assessing the amount of live $\mathrm{CD}^{+}{ }^{+}$or $\mathrm{CD}^{+} \mathrm{T}$ cells expressing at least one of the following T-cell functions: TNF, IFN $\gamma$ or CD107a (LAMP-1). These three functions were chosen on the basis of previous data with MM-reactive TILs, which expressed at least one of these three functions in $>90 \%$ of cases (10). A specific antitumor response was defined as the detection of responses larger than twice the background (i.e. unstimulated samples) with a minimum number of 
50 positive events and at least a difference of $0.5 \%$ from the background. The frequency of tumorreactive cells in stimulated samples was subtracted from unstimulated samples. $0.5 \%$ was the limit of significance.

\section{Cytotoxicity assay}

The cytotoxic activity of TILs was tested with a standard chromium $51\left({ }^{51} \mathrm{Cr}\right)$ release assay, as described elsewhere (25). In brief, $5 \times 10^{3}{ }^{51} \mathrm{Cr}$-labelled autologous tumor cells (TCL) in duplicates were co-cultured with TILs at $37^{\circ} \mathrm{C}$ for 4 hours (maximum E/T ratio of 90:1 and titrated) in RPMI $1640+10 \%$ HS. Thereafter ${ }^{51} \mathrm{Cr}$-release was measured and percentage tumor lysis was calculated using the following formula: ((experimental release - spontaneous release)/(maximum release - spontaneous release)) x 100. In selected assays, lysis was blocked using anti-HLA class I (W6/32, BioLegend, San Diego, CA, USA) antibodies, $20 \mu \mathrm{g} / \mathrm{ml}$.

\section{Enrichment of tumor-reactive T cells}

Y-TILs were thawed and rested for 48 hours in RPMI $1640+10 \%$ HS. For autologous tumor cell stimulation TILs were co-cultured for 5 hours with autologous TCLs at an E/T ratio of 3:1. AntiCD107a antibodies (conjugated with PE or BV421, two different clones, obtained respectively from Diaclone and from BD) were added before incubation. After 5 hours of incubation cells were washed twice with PBS and stained with CD3 and CD8 antibodies and sorted by FACS using the BD FACS aria cell sorter. Sorted $\mathrm{CD}^{+} \mathrm{CD} 107 \mathrm{a}^{+}$cells were further expanded $10+10$ days in two sequential 
mini/test-REPs (adjusted for the sorted cell numbers) and antitumor-responses tested in co-culture assay with autologous TCLs (as described above).

\section{RNA extraction and PCR analysis of HLA class I APM components}

Eleven RCC-TCLs and sixteen MM-TCLs were used for these analyses. All the RCC and MM-TCLs were generated and validated in our lab as described above,except for two of the RCC-TCLs included in these analyses (Caki-1 and Caki-2) which were obtained directly from American Type Culture Collection (ATCC) and passaged for less than 10 times. Total cellular RNA from 1-5 10 5 cells/sample was extracted and subjected to qPCR analysis as recently described (26). The specific primer sequences and PCR conditions are given in Supplementary Table S1. Briefly, in vitro transcription was performed with $500 \mathrm{ng}$ RNA/sample using the RevertAid H minus first strand cDNA synthesis kit according to the supplier's suggestion (Fermentas, St. Ingbert, Germany) prior to PCR employing respective primers (Supplementary Table S1) and the Platinum SYBR Green qPCR SuperMix-UDG (Invitrogen, Karlsruhe, Germany) for amplification using 40 cycles, $90^{\circ} \mathrm{C}, 15 \mathrm{sec}, 58-60^{\circ} \mathrm{C}$ annealing temperature, $30 \mathrm{sec}$. Relative mRNA expression levels were calculated with the $\Delta \mathrm{ct}$ method and normalized to $\beta$-actin.

\section{Analysis of HLA and PD-L1 expression on tumor cells}

Semi-quantitative expression of HLA class I and II antigens on TCLs from RCC and MM were assessed by staining the freshly detached cancer cells with anti HLA-ABC or HLA-DP, DR, DQ 
antibodies or relevant isotype controls. Autologous TCLs were pretreated with $100 \mathrm{IU} / \mathrm{ml}$ IFN $\gamma$ for 72 hours or were left untreated. The tumor cells were detached, divided in FACS tubes, washed, stained with surface antibodies (only one antibody for each FACS tube) and $2 \mu 1$ 7-AAD was added to each sample 5 minutes before acquisition. To more easily compare the relative marker expression of different TCLs, voltage parameters were adjusted for each isotype-stained TCL in order to achieve similar mean fluorescence intensities (MFI) in all samples. TCLs were identified as positive for HLA class II when the MFI of the studied antibody-sample exceeded at least three times the isotype control stained and positive for PD-L1 when the MFI of the studied antibody-sample exceeded at least twice the isotype control stained.

\section{Flow cytometry data processing and statistical analysis}

For functional and phenotypic characterization analyses of tumor-reactive cells, data were initially analyzed in FlowJo 9.7.1 with Boolean combination gates. For functional characterization boolean combination gates were made for the 3 functional markers (CD107a, IFN $\gamma$ and TNF), generating seven gates each showing the percentage of $\mathrm{CD}^{+}$cells expressing a unique combination of the three markers. For phenotypic characterization of tumor-reactive TILs, live CD8 ${ }^{+} \mathrm{T}$ cells were gated on CD107a ${ }^{+}$, and boolean combination gates were made for the four surface markers (PD-1, LAG-3, TIM-3 and CD57) resulting in 16 individual gates - each showing the percentage of $\mathrm{CD}^{+} \mathrm{CD} 107 \mathrm{a}^{+}$cells expressing a unique combination of the 4 markers. TILs from the additional RCC cohort were analyzed for expression of the four surface makers in the exact same way, but not gated on CD107a ${ }^{+}$. Data were exported into Pestle 1.7 (courtesy of Dr. Roederer, Immunotechnology Section, VRC/NIAID/NIH, 
Bethesda, MD, USA), formatted and the background was subtracted. Analysis and presentation of distributions was performed using Simplified Presentation of Incredibly Complex Evaluations (SPICE) 5.35, downloaded from http://exon.niaid.nih.gov (27). In SPICE, thresholds were set at 0.1 for functional characterization analysis and 0.01 for phenotypic analysis of tumor-reactive cells. Comparison of bar charts and pie charts was performed using Wilcoxon signed rank-test and a partial permutation test respectively, as previously described (27). Other analyses were carried out with Excel 2010 or Graphpad Prism 5. The magnitude of tumor responses and HLA class I antigen expression in RCC and MM were compared with two-tailed Mann-Whitney U test. The frequency of patients with Tcell responses in RCC and MM was compared with Fisher's exact test. IFN $\gamma$-treated or untreated samples and mini-REPs with alternative cytokines in RCC were compared using paired Wilcoxon signed rank nonparametric tests. In all analyses a two-sided $P$-value of $<0.05$ was considered statistically significant and all $P$ values were presented without adjustment for multiple comparisons.

\section{Results}

\section{Expansion and phenotype of TILs}

Y-TIL cultures were established from 22/24 (92\%) primary RCC specimens. Patient and tumor characteristics are summarized in Supplementary Table S2. Median days in culture of Y-TILs were 28 days (range 14-60) and median number of TILs recovered was $177 \times 10^{6}$ (range 100-336x10 ${ }^{6}$ ).

Establishment of Y-TILs in MM was successful in all cases (17/17 samples), generally faster than RCC (median days in culture 20 days, range 13-60, $P=0.047$ vs RCC-Y-TILs) and with similar amount of cells recovered (median $190 \times 10^{6}$, range $35-352 \times 10^{6}, P=0.52$ vs RCC-Y-TILs). 
The phenotypic characteristics of Y-TILs from both RCC and MM are shown in Fig. 1. Y-TILs consisted mainly of $\mathrm{CD}^{+}$lymphocytes $(87.7 \%$ vs $89.4 \% ; P=0.79)$, with fewer $\mathrm{CD}^{-} \mathrm{CD}^{-} 6^{+} \mathrm{NK}$ cells (9.6\% vs $8.2 \% ; P=0.9)$. RCC-Y-TILs contained less $\mathrm{CD}^{+}$T cells compared to MM-Y-TILs $(25.2 \%$ vs $48.5 \% ; P=0.007)$, and showed a higher CD4/CD8 ratio in $\mathrm{RCC}(2.1$ vs $0.8 ; P=0.02$, Fig. $1 \mathrm{~A})$. A detailed analysis of the relative distribution of lymphocyte subpopulations in individual RCC-Y-TILs is shown in Supplementary Table S3, where the extent of variation between individual patients can be appreciated. $\mathrm{CD}^{+}$and $\mathrm{CD}^{+}$Y-TILs from both from RCC and MM consisted almost exclusively of effector memory cells $\left(\mathrm{T}_{\mathrm{EM}}\right.$ : $\left.\mathrm{CD} 45 \mathrm{RO}^{+}, \mathrm{CD} 45 \mathrm{RA}^{-}, \mathrm{CCR} 7^{-}\right)$, with similar median percentages of $\mathrm{CD}^{+}$ $\mathrm{T}_{\mathrm{EM}}\left(95.5 \%\right.$ vs $95 \%$, Fig. 1B) but higher percentage of $\mathrm{CD}^{+} \mathrm{T}_{\mathrm{EM}}$ in $\mathrm{RCC}(98 \%$ vs $95 \%, P=0.047)$ (Fig. 1C). The expression of CD28, CD56 and CD57 on CD8 ${ }^{+}$Y-TILs appeared similar in both tumor types with broad variations among patients (Fig. 1B). However, $\mathrm{CD} 8^{+}$and $\mathrm{CD}^{+} \mathrm{MM}^{\mathrm{Y}}$-TILs expressed more CD27 $\left(\mathrm{CD}^{+}\right.$and $\left.\mathrm{CD}^{+}, P<0.01\right)$ and $\mathrm{CD} 62 \mathrm{~L}\left(\mathrm{CD}^{+}, P=0.01 ; \mathrm{CD}^{+}, P<0.01\right)($ Figs. 1B, 1C). CD4 ${ }^{+}$MM-Y-TIL expressed more CD57 ( $\left.P=0.01\right)$ (Fig. 1C).

All 22 RCC-Y-TILs were further expanded in small-scale REPs. TILs expanded a median of 1693 fold (range 530-4395, Supplementary Table S2), which was similar to MM-TILs (Fig. 1D, only 14 RCC were tested in parallel with $11 \mathrm{MM})$. . Retrospectively, we found that randomly selected Y-TILs used for comparison of REP-expansions were established faster in MM (median days in culture 17, range 13-37) compared to RCC (median days in culture 28 , range $18-60 ; P=0.018$ ).

As expected, NK cells did not expand during the REP and disappeared from all REP cultures (Fig. 1A and Supplementary Table S2). In most cases, the CD4/CD8 ratio in RCC increased after REP, from median 2.1 (range $0.3-12.7$ ) in Y-TILs to median 3.6 (range $0.5-56.1 ; P=0.02$ ). 
In conclusion, these observations suggested that some fundamental characteristics of TILs are similar between RCC- and MM-TILs (percentage of $\mathrm{T}$ cells and of $\mathrm{T}_{\mathrm{EM}}$, expansion, large variation between individual patients). However, other characteristics (CD4/CD8 ratio, expression of CD27 and CD62L on $\mathrm{CD}^{+}$and $\mathrm{CD} 4^{+}$TILs, and expression of CD57 on CD4 ${ }^{+}$TILs) appeared different - however, since the time in culture of MM-Y-TILs was shorter than RCC-Y-TILs (20 days vs 28 days, see above), we cannot exclude that these differences are due to changes induced by prolonged in vitro culturing.

\section{Tumor-reactive $\mathrm{CDB}^{+} \mathrm{TIL}$}

We next investigated the ability of TILs to recognize autologous tumor antigens. Short-term cultured autologous TCLs, serving as a source of naturally presented autologous tumor antigens, were generated from 17/22 (77\%) RCCs. Single-cell suspensions obtained from fresh tumor digests (FTD) were available for all RCCs.

Immune recognition of RCC-TCLs by $\mathrm{CD}^{+} \mathrm{Y}$-TILs was observed in 12/17 (71\%) patients and by $\mathrm{CD}^{+}$REP-TILs in 7/17 (35\%) patients (Fig. 2). In MM, CD8 ${ }^{+}$Y-TIL responses to autologous TCLs were detected in all but one of the 14 Y-TILs analyzed $(93 \%, P=0.18$ vs RCC). The magnitude of $\mathrm{CD}^{+}$T-cell responses was weaker in RCC (in TILs with responses, $2.2 \%$ vs $10.8 \%$ in $\mathrm{MM} ; P=$ 0.0001), as shown in Fig. 2A. CD8 ${ }^{+}$T-cell responses against autologous FTDs were detected in 15/22 (68\%) RCC-Y-TILs and 13/22 (59\%) REP-TIL cultures (Figs. 2C, 2D). Although not identical, both the frequency and magnitude of $\mathrm{CD}^{+}$responses against FTDs reflected those observed against shortterm cultured TCLs. Overall, $\mathrm{CD}^{+} \mathrm{T}$-cell responses against autologous tumor antigens (either presented in TCLs or in FTDs) were detected in 17/22 (77\%) RCC-Y-TILs and 14/22 (64\%) RCC- 
REP-TILs. One patient (RCC10) had a very low response detected in REP-TILs only, thus the total number of patients with tumor-reactive CD8 ${ }^{+}$TILs was 18/22 (82\%; Figs. 2C, 2D). Cytokine production (TNF and IFN $\gamma$ ) and CD107a mobilization in $\mathrm{CD} 8^{+}$RCC-Y-TILs after co-culture with autologous TCLs are shown in two representative patients in Figs. 2E, 2F. Supplementary Table S4 shows a summary of tumor-reactivity and HLA expression on RCC TCLs in individual patients. We found that TILs that contained tumor-reactive $\mathrm{CD}^{+} \mathrm{T}$ cells had spent shorter time in culture compared to TILs without tumor-reactive $\mathrm{CD}^{+} \mathrm{T}$ cells $(P=0.02)$. This may be due to heavier T-cell infiltration, or alternatively due to a higher proliferation capacity of TILs from patient samples with tumorreactivity.

We and others have reported detectable but low magnitude T-cell responses directed to autologous MM antigens in the PBMCs of patients before treatment with immunotherapy $(20,28)$. By screening the peripheral blood of six patients with RCC in co-cultures with TCLs (PBMCs from five patients with detectable tumor-reactivity in Y-TILs were used), we did not detect responses over the limit of detection used in this study $\left(0.5 \%\right.$ of either $\mathrm{CD}^{+}$or $\mathrm{CD}^{+} \mathrm{T}$ cells, as shown in Supplementary Fig. S2). Thus, tumor-reactive $\mathrm{CD} 8^{+} \mathrm{T}$ cells were enriched in the TME.

\section{Changes in TIL reactivity during massive expansion}

Effective TIL therapy relies on in vitro generation of potent tumor-reactive TILs in numbers sufficient for clinical application. This prompted us to determine whether large quantities of tumor-reactive TIL could be expanded massively with current protocols used for TIL-expansion (REP). In both TILs from RCC and MM, we observed an overall reduced reactivity following REP compared to minimally 
expanded TILs (Y-TILs) (Supplementary Fig. S3A and Fig. 3C, D). In 5/12 RCC-TILs reactivity was lost whereas in 11 MM-TILs tumor-reactivity was never lost completely (Supplementary Fig. S3B). The proportion of tumor-reactive $\mathrm{CD}^{+}$TILs following REP appeared to drop to a larger extent in RCC-TILs compared to MM-TILs, as seen from Supplementary Fig. S3B. Nonetheless, these analyses could be biased by the low frequencies of tumor-reactive cells in RCC-Y-TILs, which in many cases are close to the detection limit - thus a small drop might have resulted in undetectable responses. We conducted additional attempts to isolate $\mathrm{CD}^{+}$tumor-reactive T cells from RCC- and MM-Y-TILs (TILs from two patients for each diagnosis) by electronic sorting of tumor-reactive cells (CD107a ${ }^{+}$) and REP the sorted cells. Similar approaches were previously conducted with success in MM (29). Despite repeated attempts, we could not generate TILs enriched with tumor-reactive $\mathrm{CD} 8^{+} \mathrm{T}$ cells from $\mathrm{RCC}$ TILs, but the same approach was successful with MM-TILs in 2/2 cases (Supplementary Fig. S4). Since previous studies have shown that the use of cytokines other than IL2 during the REP, such as IL21, IL15 and IL7, can support the expansion of exhausted T cells $(29,30)$, we tested whether combinations of IL21, IL15 and IL7 could support expansion of tumor-reactive CD8 ${ }^{+}$TILs in selected RCC-Y-TILs. We observed no difference in the magnitude of tumor-reactivity (Supplementary Fig. S5) after mini-REPs with alternative cytokine combinations vs classical REP.

To verify the cytotoxic potential of TILs, samples from five representative RCCs with detectable CD8 ${ }^{+}$ T-cell responses against autologous TCLs were tested in cytotoxicity assays. Cytotoxicity was detected but was typically low and further reduced after REP. In selected experiments, HLA class I blockade was tested and almost abrogated cytotoxicity (Supplementary Fig. S6). 


\section{Polyfunctional characterization of tumor-reactive $\mathrm{CDB}^{+} \mathrm{T}$ cells}

Polyfunctionality is a desirable feature of potent $\mathrm{CD}^{+} \mathrm{T}$ cells, well known in infections (31), but only recently described in cancer immunity $(10,32)$. This feature is known to correlate with antigensensitivity and TCR affinity for cognate antigen $(33,34)$, antigen concentration (35) and, partially, differentiation status (36). We recently showed that polyfunctional $\mathrm{T}$ cells dominate the periphery after successful TIL therapy for cancer (37). Thus, we characterized the functional patterns of tumor-reactive $\mathrm{CD}^{+} \mathrm{T}$ cells. Tumor-reactive $\mathrm{CD}^{+} \mathrm{RCC}-\mathrm{Y}$-TILs were less poly-functional compared to corresponding MM-Y-TILs, with the majority (>70\%) of tumor-reactive CD8 ${ }^{+}$RCC-Y-TIL generating only one T-cell function (monofunctional $\mathrm{CD}^{+} \mathrm{T}$ cells) upon recognition of naturally presented autologous tumor antigens, in contrast to around 50\% in MM ( $P=0.02$; Fig. 3A). The pie charts in Fig. 3B illustrate the relative distribution of TNF, IFN $\gamma$ and CD107a for RCC- and MM-reactive CD8 ${ }^{+} \mathrm{Y}^{-}$ TILs $(P=0.01)$. Only few RCC tumor-reactive $\mathrm{CD}^{+} \mathrm{Y}$-TILs produced IFN $\gamma$ compared to MM (less than $15 \%$ vs almost $50 \%, P=0.002$; Fig. $3 \mathrm{C}$ ). In contrast, more than $60 \%$ of RCC tumor-reactive $\mathrm{CD}^{+} \mathrm{T}$ cells mobilized CD107a, and more than $40 \%$ mobilized CD107a as the only function, compared to less than $20 \%$ of tumor-reactive cells in MM $(P=0.04$; Fig. 3D). TNF production was similar in RCC and MM (Fig. 3B), however we also observed high TNF production in unstimulated samples (TILs without tumor), indicating that CD107a mobilization might be a more reliable marker for T-cell reactivity in populations with small responses in RCC. TNF production in representative unstimulated samples are shown in Figs. $2 \mathrm{E}, 3 \mathrm{E}$ and $3 \mathrm{~F}$. We therefore focused on the CD8 ${ }^{+} \mathrm{CD} 107 \mathrm{a}^{+}$ tumor-reactive T cells and as indicated above, this population appeared less polyfunctional in $\mathrm{RCC}$ compared to in MM ( $P=0.07$; Supplementary Figs. S7A, S7B). 


\section{Dysfunctional profile of tumor-reactive $\mathrm{CD}^{+} \mathrm{TILS}$}

Polyfunctionality and proliferative potential can be dependent on the differentiation status of $\mathrm{T}$ cells (36). Due to quite high TNF production in unstimulated samples (TILs without tumor) and because $\mathrm{CD}^{+} \mathrm{CD} 107 \mathrm{a}^{+} \mathrm{T}$ cells appeared less polyfunctional in $\mathrm{RCC}$ compared to $\mathrm{MM}(P=0.07$ Supplementary Fig. S7A, S7B), we analyzed the differentiation/dysfunctional status of this tumorreactive T-cell population. To this end we analyzed the expression of PD-1, LAG-3, TIM-3 and CD57 on tumor-reactive $\mathrm{CD} 8^{+} \mathrm{Y}$-TILs from a smaller cohort of RCC and MM (eight patients in total). The relative distribution and combinatorial expression of these markers was similar in RCC and MM (Supplementary Fig. S8). Furthermore, we analyzed the expression of PD-1, LAG-3, TIM-3 and CD57 on unselected $\mathrm{CD}^{+}$REP-TILs from an additional cohort of RCC and MM specimens as described in materials and methods (10 patients in total) and found similar results with no difference in the relative distribution of these markers in RCC and MM (Supplementary Fig. S9).

\section{HLA class I expression and immune recognition of autologous TCLs}

Polyfunctionality can be influenced by antigen presentation (35), and altered expression of the HLA class I antigen processing and presenting machinery (APM) is an immune escape mechanism in cancer (38). We have previously shown that autologous tumor recognition of MM TILs can be increased after pretreatment with low-dose IFN $\gamma$, which induce expression of the whole HLA class I APM (9).

Therefore, we asked whether HLA class I down-regulation could explain the lower magnitude and unique functional profile of $\mathrm{CD}^{+} \mathrm{T}$-cell responses observed in $\mathrm{RCC}$ compared to MM. We analyzed 12 RCC and 14 MM-TCLs and found HLA class I to be constitutively expressed in all samples, with a 
median MFI of HLA class I surface expression in RCC of 15.3 (range 8.6-46-1) versus 12.5 (range 5.425.5) in MM ( $P=0.25$; Supplementary Fig. S10). This was associated with a constitutive expression with major APM components. Although the expression of TAP2, tapasin, $\beta_{2}$-microglobulin $\left(\beta_{2} \mathrm{~m}\right)$ and the HLA class I heavy chain (HC) was comparable, the TAP1 and LMP2 mRNA levels were expressed at higher level in RCC compared to MM (Supplementary Fig. S11). Pre-treatment of TCLs with IFN $\gamma$ increased HLA class I expression in both RCC and MM with a median MFI in RCC of 35.7 (range 2.480.3) vs 28.6 (range 7.2-48.5) in MM ( $P=0.63$; Supplementary Fig. S10). The IFN $\gamma$ mediated upregulation of HLA class I surface antigens was associated with an enhanced expression of all APM components analyzed with a similar induction level in both tumor types with the exception of TAP1 exhibiting only a 50\% induction in RCC when compared to MM (Supplementary Figs. S12 and S13). This might be due to impaired constitutive but inducible TAP1 in MM. Next, we tested whether pretreatment of TCLs with IFN $\gamma$ could improve tumor recognition. In RCC, immune recognition of CD8 ${ }^{+}$ T cells did not increase (Y-TILs, $P=0.85$; REP-TILs, $P=0.58$; Supplementary Figs. S14A, S14B). In MM, on the contrary, we have previously shown that responses can be increased after IFN $\gamma$ exposure (9), however in this small cohort the increase in tumor responses after IFN $\gamma$ exposure was not statistically significant $(P=0.13$; Supplementary Fig. S14C). This difference in upregulation of tumorrecognition between RCC and MM might be partly explained by constitutive TAP1 deficiencies in MM (which may lead to impaired tumor recognition, restored by IFN $\gamma$ ) but other, unknown factors may play a role as well.

In conclusion and in contrast to MM, these data suggested that a downregulation of HLA class I surface antigens due to impaired expression of APM components does not play a major role on $\mathrm{CD}^{+} \mathrm{T}^{\mathrm{T}}$ cellmediated recognition of RCC. 


\section{Tumor-reactive CD4 ${ }^{+}$TILs}

Tumor specific $\mathrm{CD}^{+} \mathrm{T}$-cell responses may contribute to immunological surveillance of cancers (39). In MM, CD4 ${ }^{+}$TILs recognize naturally presented tumor antigens, including neoantigens, on MHC class $\mathrm{II}^{+}$cancer cells $(10,40)$. In RCC, CD4 ${ }^{+}$T-cell responses against shared tumor antigens were previously detected in one patient (41). This prompted us to analyze whether CD4 ${ }^{+}$RCC-TILs recognize autologous tumor antigens and how this compared to MM.

HLA class II was constitutively expressed, though at low levels, in only 2/12 (17\%) RCC-TCLs tested. In comparison, 50\% MM-TCLs tested (7/14) constitutively expressed HLA class II surface antigens, which is in line with previous literature $(10,42,43)(P=0.11$ vs RCC, Supplementary Fig. S15A). As expected almost all RCC (11/12) and MM (13/14) displayed HLA class II up-regulation after treatment with IFN $\gamma$ (Supplementary Fig. S15B).

$\mathrm{CD}^{+} \mathrm{T}$-cell responses against untreated autologous TCLs were observed in only 1/17 (6\%) RCC (RCC19 - HLA II status unknown) compared to 5/14 (36\%) MM ( $P=0.07$; Fig. 4A). Pre-treatment of TCLs with IFN $\gamma$, which is known to up-regulate HLA class II presentation, restored tumor recognition of $\mathrm{CD}^{+} \mathrm{Y}$-TILs in five additional patients with RCC $(6 / 17,35 \% ; P=0.09$; Supplementary Fig. $\mathrm{S} 16 \mathrm{~A})$. This is compared to a higher rate of responders in MM $(11 / 14,79 \% ; P=0.03$ vs RCC-Y-TILs, Fig. 4B and supplementary Fig. S16B), although the frequency of responding patients with MM reported here appeared to be higher than previously reported by us in one larger cohort (10). The magnitude of $\mathrm{CD}^{+}$T-cell responses in MM (in TILs with responses; median 4.4\% (range 0.7-14.7)) was not significantly stronger than in RCC (median $1.6 \%$ (range $1.1-4.4) ; P=0.08 ;$ Fig. 4B). There 
were no differences in the frequency of $\mathrm{CD}^{+} \mathrm{T}$-cell responses in the RCC-REP-TIL population with or without IFN $\gamma\left(P=0.6\right.$; Supplementary Fig. S16C). CD4 ${ }^{+}$T-cell responses to RCC-TCLs were only observed when tumor cells were either constitutively expressing HLA class II surface molecules or upon IFN $\gamma$ treatment as previously shown in MM (9).

$\mathrm{CD}^{+} \mathrm{T}$-cell responses were detected against FTDs in 16/22 (73\%) patients RCC-Y-TILs and 14/22 (64\%) RCC-REP-TILs, including 6 patients (RCC2, RCC12, RCC17, RCC18, RCC23 and RCC28), in which no CD4 T-cell reactivity against TCLs was found, neither in the absence or presence of IFN $\gamma$ (Figs. 4C, 4D). FACS plots showing cytokine production (TNF and IFN $\gamma$ ) from CD4 ${ }^{+}$RCC-Y-TILs after co-culture with TCL are shown in a representative patient in Fig. 4E. FTDs may contain other stromal elements than solely tumor cells, including antigen presenting cells (APCs). Thus, in theory, $\mathrm{CD}^{+} \mathrm{T}$ cells may recognize APCs presenting tumor-associated antigens that are not naturally processed and presented by tumor cells. For these reasons, we hypothesized that the actual frequency of $\mathrm{CD}^{+} \mathrm{T}$ cells recognizing tumor-associated antigens may be higher than expected when using TCLs as targets.

Overall, $\mathrm{CD}^{+}{ }^{\mathrm{T}}$-cell responses in RCC-Y-TILs with direct recognition of naturally presented tumor antigens on TCLs appeared similar in frequency $(77 \%$ vs $77 \%, P=1)$ but slightly lower in magnitude [median 1.05 (range $0.52-6.6$ ) vs median 1.6 (range 0.6-14.2), $P=0.11$ ] compared to $\mathrm{CD}^{+} \mathrm{T}^{-}$-cell responses. In the whole cohort, we found only three patients with RCC $(3 / 22,14 \%)$ with no detectable $\mathrm{CD}^{+}$and/or $\mathrm{CD}^{+} \mathrm{T}$-cell responses suggesting that tumor-specific $\mathrm{T}$-cell responses occur in the majority of RCC patients $(19 / 22,86 \%)$. 


\section{Discussion}

The presence of tumor-reactive $\mathrm{T}$ cells in the microenvironment of cancers appears a pre-requisite for the efficacy of PD-1 blocking agents (44) and adoptive transfer with autologous TILs which is based on TIL isolation and expansion. High expression of immune activation markers in situ (45-47) and depletion of immunogenic neoepitopes (45) suggested that the TME of primary RCCs might harbor tumor-specific T cells with immune-surveillance functions. In comparison, other highly immunogenic tumors such as MM, where current immunotherapies with PD-1/PDL1 inhibitors has so far shown the highest response rates (48), displayed only average immune activation at the tumor site (45) in spite of a higher mutational burden (49). A high proportion and number of indels in RCC tumors providing high-affinity neoepitopes may explain the high rate of $\mathrm{T}$ cell activation and clinical responses to PD-1 checkpoint inhibitors in this tumor type (50).

In this study, MM was chosen as reference comparison primarily because the infusion of autologous TILs could cure patients with widely metastatic disease in several independent studies $(1,4,6,20)$. Minimally expanded TILs from MM contain large fractions of $\mathrm{CD}^{+}$and $\mathrm{CD}^{+}$tumor-reactive $\mathrm{T}$ cells which recognize different types of antigens, including mutant neoantigens $(40,51)$. Therefore, the ability to manufacture TILs with similar features of those observed in MM warrants testing of TIL immunotherapy in other tumors. Here, we showed that naturally occurring tumor-reactive T cells can be detected, recovered and expanded in vitro from a large fraction of RCC patients. Despite some differences such as CD4/CD8 ratio, the phenotype of TILs recovered from RCCs appeared similar to MM-TILs. Tumor-reactive T cells were recovered from the TME in $86 \%$ of RCCs, with over $50 \%$ of specimens bearing tumor-reactive $\mathrm{CD}^{+} \mathrm{T}$ cells, which in many cases could directly recognize tumor cells. However, in comparison to TILs from MM, antitumor responses appeared weaker with typically 
only a few percent of $\mathrm{T}$ cells able to recognize autologous tumor antigens. Other studies have analyzed the phenotype and function of TILs in non-melanoma solid tumor histologies. The analysis of TIL phenotype showed similar results in most studies published to date, with the majority of expanded cells expressing markers consistent with antigen-experienced effector memory cells $(14,52)$. In five recent studies from the National Cancer Institute, Surgery Branch (Bethesda, MD, USA), TILs from gastrointestinal (GI) cancers were characterized (14,53-56). In two clinical cases, infusion of TILs recognizing mutant antigens induced tumor regression $(55,56)$. Nevertheless, although tumors from the majority of patients contained tumor-reactive T cells $(14,53)$, the frequency of unselected tumorreactive TILs reported in these studies was low (0-3\%) compared to MM (14). In another study from the same group, Stevanovic and coauthors (15) treated nine patients with cervical cancer with autologous TILs. Clinical responses were observed in three patients treated with TILs with high HPVreactivity. TIL-reactivity was demonstrated in 6/9 (66\%) patients with a CD137 up-regulation assay, but it appeared that three patients without clinical responses had low in vitro reactivity. Preliminary results in head and neck (57) as well as ovarian cancer (58) sarcoma (59) and uveal melanoma (60) demonstrated that tumor-reactive TILs could be recovered from the TME of all these types of tumors. Overall, it appears that tumor-reactive TILs can be recovered from most tumor types studied. However, the magnitudes of responses appear lower than in MM and can vary between individual patients. Taken together, these data warrant further development of methods for enrichment, including selection of TIL micro-cultures with particularly high antigen reactivity $(55,56)$, sorting based on activation markers upon antigen recognition (61) or streptamer-based enrichment (62). However, in this study we also show that classical REP with IL2 or combinations of IL7, IL15 and IL21 does not efficiently support the expansion of tumor-reactive TILs from RCC. A dysfunctional profile of tumor-reactive TILs did 
not appear to be associated with a lower proliferative potential. Thus, further studies should explore other ways to expand massively tumor-reactive TILs from RCC.

Polyfunctionality is a desirable feature of potent $\mathrm{CD}^{+} \mathrm{T}$ cells that is often found in infections (31), but described less frequently in cancer immunity $(10,32)$. Tumor-reactive $\mathrm{CD} 8^{+} \mathrm{T}$ cells in RCC were less polyfunctional compared to their MM counterpart, and especially produced less IFN $\gamma$. These data may explain the discrepancy previously observed by Markel et al. (11), who reported data on six pairs of TILs and autologous RCC lines with cytotoxicity without IFN $\gamma$ production in three of six patients analyzed. In our study, lower poly-functionality compared to MM did not appear to associate to a more exhausted profile of tumor-reactive $\mathrm{CD}^{+} \mathrm{T}$ cells. However, poly-functionality may be a function of the intensity of stimulation of the T-cell receptor (TCR), influenced by the densities of HLA class Iantigen complexes on the target cells and antigen sensitivity of the effector T cell $(35,63)$. According to data obtained with virus-specific $\mathrm{CD}^{+} \mathrm{T}$ cells, $\mathrm{CD} 107$ a mobilization is influenced to a minor extent by antigen concentration compared to IFN $\gamma$, and this may explain why RCC-specific $\mathrm{CD}^{+} \mathrm{T}$ cells mobilized CD107a but did not produce IFN $\gamma$. Since we could not identify target antigens in RCC, we were not able to determine whether the RCC-tumor-reactive TILs had lower antigen sensitivity, or their cognate antigens were expressed at lower levels on target cells. However, RCC cell lines exhibit comparable constitutive and IFN $\gamma$-inducible expression levels of major APM components and HLA class I surface molecules when compared to MM. In contrast to MM, global tumor-recognition of RCC-TCLs was not increased upon pre-exposure to IFN $\gamma$ despite increase of HLA class I surface antigens. Thus, universal downregulation of HLA class I antigens did not appear to be a major issue in $\mathrm{RCC}$, and is unlikely to be responsible for the mono/oligo-functional responses observed. Further studies to determine whether primary functional deficiencies of RCC-tumor reactive CD8 ${ }^{+}$TILs may 
induce this unique functional profile are ongoing at our laboratory. Nonetheless, these findings provide guidance for immuno-monitoring studies in RCC where IFN $\gamma$ assays (e.g. IFN $\gamma$ ELISPOT or ELISA, which are commonly used for this purpose) might not detect otherwise tumor-reactive $\mathrm{CD}^{+} \mathrm{T}$ cells.

The role of tumor-reactive CD4 ${ }^{+}$TILs in cancer is currently a matter of debate. In MM, it was demonstrated that the TME of most patients contain $\mathrm{CD} 4^{+}$TILs which can recognize tumor-antigens, including products of cancer-mutations, presented directly from tumor cells in association with HLA class II $(10,40,64)$. Direct infusion of $\mathrm{CD}^{+} \mathrm{T}$ cells enriched for recognition of one mutant antigen mediated tumor regression of a GI cancer (55). However, the beneficial role of tumor-reactive $\mathrm{CD}^{+} \mathrm{T}^{\mathrm{T}}$ cells in MM was recently questioned by our group through the demonstration of a mono-functional pattern in most effector cells (10). 50\% of MM express constitutively HLA class II molecules $(10,42)$, and this is known to associate with stronger tumor-specific $\mathrm{CD}^{+} \mathrm{T}$-cell responses (10). In this study, only 2/12 (17\%) RCC expressed HLA class II constitutively, but up-regulation of HLA class II molecules with cytokines revealed $\mathrm{CD}^{+}$tumor-recognition in over $50 \%$ of patients. These data demonstrate that generation of tumor-specific $\mathrm{CD}^{+} \mathrm{T}$ cells is a frequent event in primary RCC, but therapeutic exploitation of direct $\mathrm{CD}^{+}{ }^{+} \mathrm{T}$-cell responses will require up-regulation of HLA class II molecules by other means, such as co-transfer of tumor-reactive $\mathrm{CD} 8^{+} \mathrm{T}$ cells to produce IFN $\gamma$ in the TME.

This study suffers from two intrinsic drawbacks. First, the samples used in this study were obtained from primary RCC, which were compared to metastases of melanoma. Second, RCC lesions are known to have high inter- and intra-tumor heterogeneity $(19,65)$. However, a study characterizing the TME and its prognostic relevance in primary vs metastatic clear cell RCC found a comparable immune cell infiltration pattern in primary to metastatic tumors (66). Third, RCC are generally highly vascularized 
tumors, which increase the risk for contamination of TIL cultures with PBLs and thereby diluting tumor-reactive cells. This might contribute to the low tumor responses observed, but does not explain the differences in functionality of $\mathrm{CD}^{+}$tumor-reactive TILs. If RCC lesions will be used for the generation of clinical grade TILs, one would have to be careful to not contaminate TIL cultures with PBLs, and thus diluting tumor-reactive cells in the TIL product.

In conclusion, TILs from RCC can be expanded to clinical relevant numbers using the Young-TIL expansion methods, and TILs obtained from most patients contain tumor-reactive CD $4^{+}$and $\mathrm{CD} 8^{+} \mathrm{T}$ cells. However, immune responses of expanded TILs from RCC are on average weaker and less polyfunctional than observed in MM. The ability to select, enrich and expand tumor-reactive polyfunctional T cells may be critical in developing effective ACT with autologous TILs for RCC.

\section{Acknowledgements}

Lisbeth Egelykke Stolpe, Sandra Ullitz Færch and Susanne Wendt are acknowledged for technical assistance. Lillian Føns is acknowledged for assistance in patient inclusion. The studies were supported by grants from the Research Council from Herlev Hospital and The Danish Cancer Research foundation and the Mildred Scheel Cancer Aid Foundation (BS) grant110703 and 111091.

\section{References}

1. Rosenberg SA, Yang JC, Sherry RM, Kammula US, Hughes MS, Phan GQ, et al. Durable 
complete responses in heavily pretreated patients with metastatic melanoma using T-cell transfer immunotherapy. Clin Cancer Res [Internet]. 2011;17:4550-7. Available from:

http://www.pubmedcentral.nih.gov/articlerender.fcgi?artid=3131487\&tool=pmcentrez\&renderty pe $=$ abstract

2. Dudley ME, Yang JC, Sherry R, Hughes MS, Royal R, Kammula U, et al. Adoptive cell therapy for patients with metastatic melanoma: evaluation of intensive myeloablative chemoradiation preparative regimens. J Clin Oncol [Internet]. 2008 [cited 2012 Nov 1];26:5233-9. Available from:

http://www.pubmedcentral.nih.gov/articlerender.fcgi?artid=2652090\&tool=pmcentrez\&renderty pe $=$ abstract

3. Besser MJ, Shapira-Frommer R, Treves AJ, Zippel D, Itzhaki O, Hershkovitz L, et al. Clinical responses in a phase II study using adoptive transfer of short-term cultured tumor infiltration lymphocytes in metastatic melanoma patients. Clin cancer Res [Internet]. 2010 [cited 2012 Nov 29];16:2646-55. Available from: http://www.ncbi.nlm.nih.gov/pubmed/20406835

4. Besser MJ, Shapira-Frommer R, Itzhaki O, Treves AJ, Zippel DB, Levy D, et al. Adoptive transfer of tumor-infiltrating lymphocytes in patients with metastatic melanoma: intent-to-treat analysis and efficacy after failure to prior immunotherapies. Clin cancer Res [Internet]. 2013 [cited 2014 Jul 1];19:4792-800. Available from:

http://www.ncbi.nlm.nih.gov/pubmed/23690483

5. Pilon-Thomas S, Kuhn L, Ellwanger S, Janssen W, Royster E, Marzban S, et al. Efficacy of adoptive cell transfer of tumor-infiltrating lymphocytes after lymphopenia induction for metastatic melanoma. J Immunother [Internet]. 2012;35:615-20. Available from:

http://www.ncbi.nlm.nih.gov/pubmed/22996367

6. Radvanyi LG, Bernatchez C, Zhang M, Fox PS, Miller P, Chacon J, et al. Specific lymphocyte subsets predict response to adoptive cell therapy using expanded autologous tumor-infiltrating lymphocytes in metastatic melanoma patients. Clin cancer Res [Internet]. 2012 [cited 2012 Oct 4];18:6758-70. Available from:

http://www.pubmedcentral.nih.gov/articlerender.fcgi?artid=3525747\&tool=pmcentrez\&renderty pe $=$ abstract

7. Ellebaek E, Iversen TZ, Junker N, Donia M, Engell-Noerregaard L, Met O, et al. Adoptive cell therapy with autologous tumor infiltrating lymphocytes and low-dose Interleukin-2 in metastatic melanoma patients. J Transl Med [Internet]. 2012 [cited 2012 Aug 27];10:169. Available from: http://www.pubmedcentral.nih.gov/articlerender.fcgi?artid=3514199\&tool=pmcentrez\&renderty pe $=$ abstract

8. Hinrichs CS, Rosenberg S a. Exploiting the curative potential of adoptive T-cell therapy for cancer. Immunol Rev [Internet]. 2014;257:56-71. Available from: http://www.ncbi.nlm.nih.gov/pubmed/24329789

9. Donia M, Hansen M, Sendrup SL, Iversen TZ, Ellebæk E, Andersen MH, et al. Methods to Improve Adoptive T-Cell Therapy for Melanoma: IFN- $\gamma$ Enhances Anticancer Responses of Cell Products for Infusion. J Invest Dermatol [Internet]. 2012 [cited 2012 Nov 8];133:545-52. Available from: http://www.ncbi.nlm.nih.gov/pubmed/23014345 
10. Donia M, Andersen R, Kjeldsen JW, Fagone P, Munir S, Nicoletti F, et al. Aberrant expression of MHC Class II in melanoma attracts inflammatory tumor specific CD4+ T cells which dampen CD8+ T cell antitumor reactivity. Cancer Res [Internet]. 2015;75:3747-60. Available from: http://cancerres.aacrjournals.org/cgi/doi/10.1158/0008-5472.CAN-14-2956

11. Markel G, Cohen-Sinai T, Besser MJ, Oved K, Itzhaki O, Seidman R, et al. Preclinical evaluation of adoptive cell therapy for patients with metastatic renal cell carcinoma. Anticancer Res [Internet]. 2009 [cited 2012 Jun 20];29:145-54. Available from: http://www.ncbi.nlm.nih.gov/pubmed/19331144

12. Wang QJ, Hanada K-I, Robbins PF, Li YF, Yang JC. Distinctive features of the differentiated phenotype and infiltration of tumor-reactive lymphocytes in clear cell renal cell carcinoma. Cancer Res [Internet]. 2012 [cited 2013 May 24];72:6119-29. Available from: http://www.ncbi.nlm.nih.gov/pubmed/23071066

13. Baldan V, Griffiths R, Hawkins RE, Gilham DE. Efficient and reproducible generation of tumour-infiltrating lymphocytes for renal cell carcinoma. Br J Cancer [Internet]. Nature Publishing Group; 2015;1-9. Available from: http://www.nature.com/doifinder/10.1038/bjc.2015.96

14. Turcotte S, Gros A, Hogan K, Tran E, Hinrichs CS, Wunderlich JR, et al. Phenotype and Function of T Cells Infiltrating Visceral Metastases from Gastrointestinal Cancers and Melanoma: Implications for Adoptive Cell Transfer Therapy. J Immunol [Internet]. 2013 [cited 2013 Aug 8];191:2217-25. Available from: http://www.ncbi.nlm.nih.gov/pubmed/23904171

15. Stevanović S, Draper LM, Langhan MM, Campbell TE, Kwong ML, Wunderlich JR, et al. Complete Regression of Metastatic Cervical Cancer After Treatment With Human Papillomavirus-Targeted Tumor-Infiltrating T Cells. J Clin Oncol [Internet]. 2015;33. Available from: http://jco.ascopubs.org/cgi/doi/10.1200/JCO.2014.58.9093

16. Andersen R, Donia M, Westergaard MCW, Pedersen M, Hansen M, Svane IM. Tumor infiltrating lymphocyte therapy for ovarian cancer and renal cell carcinoma. Hum Vaccin Immunother [Internet]. 2015;11:2790-5. Available from: http://www.tandfonline.com/doi/full/10.1080/21645515.2015.1075106

17. Fyfe G, Fisher RI, Rosenberg SA, Sznol M, Parkinson DR, Louie AC. Results of treatment of 255 patients with metastatic renal cell carcinoma who received high-dose recombinant interleukin-2 therapy. J Clin Oncol. 1995;13:688-96.

18. Motzer RJ, Escudier B, McDermott DF, George S, Hammers HJ, Srinivas S, et al. Nivolumab versus Everolimus in Advanced Renal-Cell Carcinoma. N Engl J Med [Internet]. 2015;1803-13. Available from: http://www.ncbi.nlm.nih.gov/pubmed/26406148

19. Gerlinger M, Rowan AJ, Horswell S, Larkin J, Endesfelder D, Gronroos E, et al. Intratumor Heterogeneity and Branched Evolution Revealed by Multiregion Sequencing. N Engl J Med. 2012;366:883-92.

20. Andersen R, Donia M, Ellebæk E, Borch TH, Kongsted P, Iversen TZ, et al. Long-lasting complete responses in patients with metastatic melanoma after adoptive cell therapy with tumor- 
infiltrating lymphocytes and an attenuated IL-2 regimen. Clin Cancer Res [Internet]. 2016;22:1078-0432.CCR-15-1879-. Available from: http://clincancerres.aacrjournals.org/content/early/2016/03/22/1078-0432.CCR-15-1879.long

21. Donia M, Junker N, Ellebaek E, Andersen MH, Straten PT, Svane IM. Characterization and comparison of "Standard" and "Young" tumor infiltrating lymphocytes for adoptive cell therapy at a Danish Translational Research Institution. Scand J Immunol [Internet]. 2011 [cited 2012 May 11];157-67. Available from: http://www.ncbi.nlm.nih.gov/pubmed/21955245

22. Fischer AH, Zhao C, Li QK, Gustafson KS, Eltoum I-EE, Tambouret R, et al. The cytologic criteria of malignancy. J Cell Biochem [Internet]. 2010 [cited 2014 Nov 29];110:795-811. Available from: http://www.ncbi.nlm.nih.gov/pubmed/20564180

23. Andersen R, Donia M, Ellebaek E, Borch TH, Kongsted P, Iversen TZ, et al. skal slettes. Clin Cancer Res. 2016;22.

24. Donia M, Andersen R, Kjeldsen JW, Fagone P, Munir S, Nicoletti F, et al. Aberrant skal slettes. Cancer Res. 2015;75.

25. Andersen MH, Bonfill JE, Neisig A, Arsequell G, Sondergaard I, Valencia G, et al. Phosphorylated peptides can be transported by TAP molecules, presented by class I MHC molecules, and recognized by phosphopeptide-specific CTL. J Immunol [Internet]. 1999;163:3812-8. Available from:

http://www.ncbi.nlm.nih.gov/pubmed/10490979\%5Cnhttp://www.jimmunol.org/content/163/7/3 812.full.pdf

26. Steven A, Leisz S, Massa C, Iezzi M, Lattanzio R, Lamolinara A, et al. HER-2/neu mediates oncogenic transformation via altered CREB expression and function. Mol Cancer Res [Internet]. 2013;11:1462-77. Available from: http://mcr.aacrjournals.org/content/11/11/1462.abstract

27. Roederer M, Nozzi JL, Nason MC. SPICE: Exploration and analysis of post-cytometric complex multivariate datasets. Cytom Part A [Internet]. 2011 [cited 2014 Mar 20];79 A:167-74.

Available from:

http://www.pubmedcentral.nih.gov/articlerender.fcgi?artid=3072288\&tool=pmcentrez\&renderty pe $=$ abstract

28. Kvistborg P, Shu CJ, Heemskerk B, Fankhauser M, Thrue CA, Toebes M, et al. TIL therapy broadens the tumor-reactive CD8+ T cell compartment in melanoma patients. Oncoimmunology. 2012;1:409-18.

29. Ye Q, Song D-G, Poussin M, Yamamoto T, Best A, Li C, et al. CD137 accurately identifies and enriches for naturally occurring tumor-reactive T cells in tumor. Clin cancer Res [Internet]. 2014 [cited 2014 Jan 20];20:44-55. Available from: http://www.ncbi.nlm.nih.gov/pubmed/24045181

30. Li Y, Liu S, Hernandez J, Vence L, Hwu P, Radvanyi L. MART-1-specific melanoma tumorinfiltrating lymphocytes maintaining CD28 expression have improved survival and expansion capability following antigenic restimulation in vitro. J Immunol [Internet]. 2010 [cited 2012 Dec 14];184:452-65. Available from: http://www.ncbi.nlm.nih.gov/pubmed/19949105

31. Seder RA, Darrah PA, Roederer M. T-cell quality in memory and protection: implications for 
vaccine design. Nat Rev Immunol [Internet]. 2008 [cited 2014 Nov 14];8:247-58. Available from:

http://www.ncbi.nlm.nih.gov/pubmed/18323851\%5Cnhttp://www.nature.com/nri/journal/v8/n4/ pdf/nri2274.pdf

32. Berinstein NL, Karkada M, Oza AM, Odunsi K, Villella JA, Nemunaitis JJ, et al. Survivintargeted immunotherapy drives robust polyfunctional $\mathrm{T}$ cell generation and differentiation in advanced ovarian cancer patients. Oncoimmunology. 2015;4:e1026529.

33. Tan MP, Gerry AB, Brewer JE, Melchiori L, Bridgeman JS, Bennett AD, et al. T cell receptor binding affinity governs the functional profile of cancer-specific CD8+ T cells. Clin Exp Immunol. 2015;180:255-70.

34. Tan MP, Dolton GM, Gerry AB, Brewer JE, Bennett AD, Pumphrey NJ, et al. Human leucocyte antigen class I-redirected anti-tumour $\mathrm{CD} 4{ }^{+} \mathrm{T}$ cells require a higher $\mathrm{T}$ cell receptor binding affinity for optimal activity than $\mathrm{CD}^{+}{ }^{+} \mathrm{T}$ cells. Clin Exp Immunol. 2016;

35. Almeida J, Sauce D, Price D, Papagno L, Shin S, Moris A, et al. Antigen sensitivity is a major determinant of CD8+ T-cell polyfunctionality and HIV suppressive activity. Blood. 2009;6:P246.

36. Karagiannis P, Iriguchi S, Kaneko S. Reprogramming away from the exhausted T cell state. Semin Immunol [Internet]. Elsevier Ltd; 2016;28:35-44. Available from: http://dx.doi.org/10.1016/j.smim.2015.10.007

37. Donia M, Kjeldsen JW, Andersen R, Wulff MC, Bianchi V, Legut M, et al. PD-1+ polyfunctional $\mathrm{T}$ cells dominate the periphery after tumor-infiltrating lymphocyte therapy for cancer. Clin Cancer Res. 2017; jul 5.

38. del Campo A, Carretero J, Aptsiauri N, Garrido F. Targeting HLA class I expression to increase tumor immunogenicity. Tissue Antigens [Internet]. 2012;79:147-54. Available from: http://www.ncbi.nlm.nih.gov/pubmed/22309256

39. Hadrup S, Donia M, Thor Straten P. Effector CD4 and CD8 T Cells and Their Role in the Tumor Microenvironment. Cancer Microenviron [Internet]. 2012 [cited 2012 Dec 29];6:123-33. Available from: http://www.ncbi.nlm.nih.gov/pubmed/23242673

40. Linnemann C, van Buuren MM, Bies L, Verdegaal EME, Schotte R, Calis JJA, et al. Highthroughput epitope discovery reveals frequent recognition of neo-antigens by CD4+ T cells in human melanoma. Nat Med. Nature Publishing Group; 2014;1-7.

41. Mautner J, Jaffee EM, Pardoll DM. Tumor-specific CD4+ T cells from a patient with renal cell carcinoma recognize diverse shared antigens. Int J cancer [Internet]. 2005;115:752-9. Available from: http://www.ncbi.nlm.nih.gov/pubmed/15704175

42. Mendez R, Aptsiauri N, Del Campo A, Maleno I, Cabrera T, Ruiz-Cabello F, et al. HLA and melanoma: multiple alterations in HLA class I and II expression in human melanoma cell lines from ESTDAB cell bank. Cancer Immunol Immunother [Internet]. 2009 [cited 2012 Dec 14];58:1507-15. Available from: http://www.ncbi.nlm.nih.gov/pubmed/19340423 
43. Seliger B, Kloor M, Ferrone S. HLA class II antigen-processing pathway in tumors: Molecular defects and clinical relevance. Oncoimmunology [Internet]. Taylor \& Francis; 2017;6:e1171447. Available from: https://www.tandfonline.com/doi/full/10.1080/2162402X.2016.1171447

44. Tumeh PC, Harview CL, Yearley JH, Shintaku IP, Taylor EJM, Robert L, et al. PD-1 blockade induces responses by inhibiting adaptive immune resistance. Nature [Internet]. 2014 [cited 2014 Nov 26];515:568-71. Available from: http://www.nature.com/doifinder/10.1038/nature13954

45. Rooney MS, Shukla SA, Wu CJ, Getz G, Hacohen N. Molecular and genetic properties of tumors associated with local immune cytolytic activity. Cell [Internet]. Elsevier Inc.; 2015;160:48-61. Available from: http://dx.doi.org/10.1016/j.cell.2014.12.033

46. Spranger S, Luke JJ, Bao R, Zha Y, Hernandez KM, Li Y, et al. Density of immunogenic antigens does not explain the presence or absence of the T-cell-inflamed tumor microenvironment in melanoma. Proc Natl Acad Sci. 2016;11:E7759-NaN-7768.

47. Senbabaoglu Y, Gejman RS, Winer AG, Liu M, Van Allen EM. Tumor immune microenvironment characterization in clear cell renal cell carcinoma identifies prognostic and immunotherapeutically relevant messenger RNA signatures. Genome Biol [Internet]. 2016; 17:231. Available from: http://genomebiology.biomedcentral.com/articles/10.1186/s13059-016-1092z\%255Cnhttp://www.ncbi.nlm.nih.gov/pubmed/27855702

48. Borch TH, Donia M, Andersen MH, Svane IM. Reorienting skal slettes. Drug Discov Today [Internet]. Elsevier Ltd; 2015;20:1127-34. Available from: http://linkinghub.elsevier.com/retrieve/pii/S1359644615002743

49. Alexandrov LB, Nik-Zainal S, Wedge DC, Aparicio S a JR, Behjati S, Biankin A V, et al. Signatures of mutational processes in human cancer. Nature [Internet]. 2013 [cited 2014 Jul 9];500:415-21. Available from:

http://www.pubmedcentral.nih.gov/articlerender.fcgi?artid=3776390\&tool=pmcentrez\&renderty pe $=$ abstract

50. Turajlic S, Litchfield K, Xu H, Rosenthal R, McGranahan N, Reading JL, et al. Insertion-anddeletion-derived tumour-specific neoantigens and the immunogenic phenotype: a pan-cancer analysis. Lancet Oncol [Internet]. The Author(s). Published by Elsevier Ltd. This is an Open Access article under the CC BY 4.0 license; 2017;18:1009-21. Available from: http://dx.doi.org/10.1016/S1470-2045(17)30516-8

51. Robbins PF, Lu Y-C, El-Gamil M, Li YF, Gross C, Gartner J, et al. Mining exomic sequencing data to identify mutated antigens recognized by adoptively transferred tumor-reactive $\mathrm{T}$ cells. Nat Med [Internet]. Nature Publishing Group; 2013 [cited 2013 Aug 8];19:747-52. Available from: http://www.ncbi.nlm.nih.gov/pubmed/23644516

52. Chandran SS, Paria BC, Srivastava AK, Rotherme LD, Stephens DJ, Kammula US, et al. Tumor-specific effector CD8+ T cells that can establish immunological memory in humans after adoptive transfer are marked by expression of IL7 receptor and c-myc. Cancer Res [Internet]. 2015;75:3216-26. Available from: http://cancerres.aacrjournals.org/cgi/doi/10.1158/00085472.CAN-15-0584 
53. Turcotte S, Gros A, Tran E, Lee CCR, Wunderlich JR, Robbins PF, et al. Tumor-Reactive CD8+ $\mathrm{T}$ cells in metastatic gastrointestinal cancer refractory to chemotherapy. Clin Cancer Res. 2014;20:331-43.

54. Tran E, Ahmadzadeh M, Lu Y, Gros A, Turcotte S, Robbins PF, et al. Immunogenicity skal slettes. Science (80- ). 2015;350:1387-91.

55. Tran E, Turcotte S, Gros A, Robbins P. Cancer Immunotherapy Based on Mutation-Specific CD4+ T Cells in a Patient with Epithelial Cancer. Science (80- ) [Internet]. 2014 [cited 2015 Jan 6];9:641-6. Available from: http://www.sciencemag.org/content/344/6184/641.short

56. Tran E, Robbins PF, Lu Y-C, Prickett TD, Gartner JJ, Jia L, et al. T-Cell Transfer Therapy Targeting Mutant KRAS in Cancer. N Engl J Med [Internet]. 2016;375:2255-62. Available from: http://www.nejm.org/doi/10.1056/NEJMoa1609279

57. Junker N, Andersen MH, Wenandy L, Dombernowsky SL, Kiss K, Sørensen CH, et al. Bimodal ex vivo expansion of $\mathrm{T}$ cells from patients with head and neck squamous cell carcinoma: a prerequisite for adoptive cell transfer. Cytotherapy [Internet]. 2011 [cited 2012 Aug 27];13:82234. Available from: http://www.ncbi.nlm.nih.gov/pubmed/21428850

58. Westergaard M christine W, Andersen R, Kjeldsen JW, Hasselager T, Lajer H, Donia M, et al. Preclinical development of tumor-infiltrating lymphocytes (TILs) based adoptive cell transfer immunotherapy (ACT) for patients with advanced ovarian cancer. Ann Oncol. 2016;27 (suppl_.

59. Nielsen M, Krarup-Hansen A, Hovgaard D, Petersen MM, Loya AC, Junker N, et al. Preclinical development of tumor infiltrating lymphocyte (TIL) based adoptive cell transfer (ACT) immunotherapy for patients with sarcoma. JITC. 2016; Volume 4,:Abstract P34.

60. Rothermel LD, Sabesan AC, Stephens DJ, Chandran SS, Paria BC, Srivastava AK, et al. Identification of an Immunogenic Subset of Metastatic Uveal Melanoma. Clin Cancer Res. 2016;22:2237-49.

61. Rosenberg SA, Restifo NP. Adoptive cell transfer as personalized immunotherapy for human cancer. Cancer Immunol Immunother. 2015;348:62-8.

62. Kelderman S, Heemskerk B, Fanchi L, Philips D, Toebes M, Kvistborg P, et al. Antigen-specific TIL therapy for melanoma: A flexible platform for personalized cancer immunotherapy. Eur J Immunol. 2016;46:1351-60.

63. Chiu YL, Shan L, Huang H, Haupt C, Bessell C, Canaday DH, et al. Sprouty-2 regulates HIVspecific T cell polyfunctionality. J Clin Invest. 2014;124:198-208.

64. Friedman KM, Prieto PA, Devillier LE, Gross CA, Yang JC, Wunderlich JR, et al. Tumorspecific CD4+ Melanoma Tumor-infiltrating lymphocytes. J Immunother. 2012;35:400-8.

65. Fisher R, Larkin J, Swanton C. Inter and intratumour heterogeneity: a barrier to individualized medical therapy in renal cell carcinoma? Front Oncol [Internet]. 2012 [cited 2012 Oct 1];2:49. Available from: http://www.pubmedcentral.nih.gov/articlerender.fcgi?artid=3356118\&tool=pmcentrez\&renderty pe $=$ abstract 
66. Remark R, Alifano M, Cremer I, Lupo A, Dieu-Nosjean M-CC, Riquet M, et al. Characteristics and Clinical Impacts of the Immune Environments in Colorectal and Renal Cell Carcinoma Lung Metastases: Influence of Tumor Origin. Clin cancer Res [Internet]. 2013 [cited 2013 Jul 11];19:4079-91. Available from: http://www.ncbi.nlm.nih.gov/pubmed/23785047

\section{Figure legends}

Figure 1. Phenotypic characterization of Y-TIL and Rapid Expansion Protocol (REP).

$(\mathbf{A}, \mathbf{B}, \mathbf{C})$ The figures show the phenotype of in vitro expanded Y-TIL from 22 RCC and 17 MM specimens.(A) The pie charts illustrate the phenotype characteristics of all RCC and MM patients analyzed. Median values of the proportion of TILs expressing the following surface markers are shown: $\mathrm{CD}^{+} \mathrm{CD}^{+}, \mathrm{CD}^{+} \mathrm{CD} 4^{+}, \mathrm{CD}^{+} \mathrm{CD}^{+} \mathrm{CD}^{+}, \mathrm{CD}^{+} \mathrm{CD}^{-} \mathrm{CD} 8^{-}$and $\left.\mathrm{CD}^{-} \mathrm{CD} 56^{+}\right)$. RCC-Y-TILs contained less $\mathrm{CD}^{+} \mathrm{T}$-cells $(P=0.007)$ and more $\mathrm{CD} 4^{+} \mathrm{T}$ cells than MM-Y-TIL, however this difference was not statistically significant $(P=0.09)$. $(\mathbf{B}, \mathbf{C})$ Dot plots show the proportion of Y-TILs expressing the depicted phenotypic markers on $\mathrm{CD}^{+}(\mathbf{B})$ and $\mathrm{CD}^{+} \mathrm{T}$ cells $(\mathbf{C})$ in $\mathrm{RCC}(n=22$, grey dots) and $\mathrm{MM}$ ( $n=17$, black triangles). Abbreviations: $\mathrm{T}_{\mathrm{EM}}=\mathrm{T}$ effector Memory $\left(\mathrm{CD} 45 \mathrm{RO}^{+}\right.$, $\mathrm{CD}^{2} 5 \mathrm{RA}^{-}, \mathrm{CCR}^{-}$). Lines show median values. ${ }^{*}, P<0.05 ; * *, P \leq 0.01 ; * * *, P \leq 0.001$. (D) To directly compare the expansion capacity in RCC and MM, small scale REPs in 14 randomly selected RCC-samples (performed in duplicates) were carried out in parallel with $11 \mathrm{MM}$ samples (performed in duplicates). The fold expansion of TILs during REP was similar in RCC (grey dots) and MM (black 
triangles): median fold expansion on day $7(P=0.17)$, day $9(P=0.08)$, day $12(P=0.7)$ or on day 14 $(P=0.3)$. Lines show median values. $(\mathbf{E})$ The FACS plots illustrate the proportion of CD ${ }^{+}$TILs staining positive for CD4 and CD8 from a representative patient (RCC16).

\section{Figure 2. $\mathrm{CD8}^{+} \mathrm{T}$-cell responses in $\mathrm{RCC}$ and $\mathrm{MM}$}

The figure shows antitumor $\mathrm{CD}^{+}$T-cell responses in RCC- $(n=17)$ and MM- $(n=14)$ Y-TILs and REP-TILs after co-culture with autologous fresh tumor digests (FTD) or tumor cell lines (TCLs), treated with IFN $\gamma(\mathrm{TCL}+\mathrm{IFN} \gamma)$ or left untreated (TCL), as described in materials and methods. Tumor-reactive $\mathrm{T}$ cells are defined as $\mathrm{T}$ cells expressing at least one of the following T-cell functions: TNF, IFN $\gamma$ or CD107a. (A and B) Upper panels: the number/(\%) of patients containing Y-TILs with (dark grey) or without (light grey) $\mathrm{CD}^{+} \mathrm{T}$-cell responses against TCLs $+/$ - IFN $\gamma$ is shown in the pie charts. No significant difference was found when comparing CD8 ${ }^{+} \mathrm{T}$-cell responses in Y-TILs cocultured with untreated TCLs from RCC and MM $(P=0.18)$, while a higher percentage of MM-TILs had $\mathrm{CD}^{+} \mathrm{T}$-cell responses towards TCLs $+\operatorname{IFN} \gamma(P=0.045)$. Lower panels: dots and triangles represent RCC- and MM-TILs respectively; black and grey symbols represent Y-TILs with or without $\mathrm{CD}^{+}$responses against TCLs $+/-$IFN $\gamma$ respectively. Limit of detection was $0.5 \%$. Lines show median values. The magnitude of $\mathrm{CD}^{+} \mathrm{T}$-cell responses in Y-TILs against autologous TCLs (both untreated and treated with IFN $\gamma$ ) were lower in RCC compared to MM (when only TILs with responses are compared: untreated TCLs $P=0.0001$; TCLs + IFN $\gamma, P=0.0007)$. (C and D) The percentages of 
tumor-reactive $\mathrm{CD}^{+}$Y-TILs $(\mathbf{C})$ and $\mathrm{CD}^{+}$REP-TILs (D) after co-culture with autologous FTDs (light grey bars), untreated TCLs (dark grey bars) or TCLs + IFN $\gamma$ (black bars) in individual RCC patients are shown. In patients where autologous TCLs were not available, TILs were only tested against FTDs (RCC3, RCC5, RCC8, RCC10 and RCC11). Dotted line: limit of detection (0.5\%). (E and F) The FACS plots demonstrate (E) cytokine production (TNF and IFN $\gamma$ ) and (F) CD107a mobilization in $\mathrm{CD}^{+}$RCC-Y-TILs after co-culture with autologous tumor cells in two representative patients (RCC26 in $\mathbf{E}$ and $\mathrm{RCC} 12$ in $\mathbf{F})$.

\section{Figure 3. Polyfunctional characterization of $\mathrm{CD8}^{+}$tumor-reactive $\mathrm{T}$ cells}

The figure shows a graphical presentation of SPICE data analyses. CD ${ }^{+}$Y-TIL subpopulations from RCC $(n=12)$ and MM $(n=13)$ were gated on cells expressing at least one of the three T-cell functions analyzed (IFN $\gamma$, TNF and CD107a) and pie charts and columns illustrate the median values. (A) The pie charts show the proportion of tumor-reactive $\mathrm{CD}^{+} \mathrm{T}$ cells generating 1,2 or 3 of the three $\mathrm{T}$-cell functions analyzed, in RCC and MM respectively. Tumor-reactive $\mathrm{CD}^{+} \mathrm{T}$ cells in RCC-Y-TILs were less polyfunctional than $\mathrm{MM}(P=0.02) .(\mathbf{B}, \mathbf{C})$ The pie charts $(\mathbf{B})$ and bar chart $(\mathbf{C})$ illustrate the relative distribution of the seven combinations of the three T-cell functions generated by tumor-reactive $\mathrm{CD}^{+} \mathrm{T}$ cells in RCC (grey bars) and MM (black bars) respectively. (B) Tumor-reactive $\mathrm{CD}^{+} \mathrm{T}^{\mathrm{T}}$ cells in RCC-Y-TILs appeared less polyfunctional compared to MM $(P=0.01$, permutation test) and (B and C) a larger fraction of T cells mobilized CD107a without production of cytokines $(P=0.04$, vs MM, corresponding to the purple pie slice). (D) The bar chart shows that a smaller fraction of tumor-reactive $\mathrm{CD}^{+} \mathrm{T}$ cells in RCC-Y-TILs produced IFN $\gamma$ compared to MM $(P=0.002)$, indicating that IFN $\gamma$ was 
most typically produced by MM-TILs. (E, F) The FACS plots demonstrate CD107a mobilization and cytokine production (TNF and IFN $\gamma$ ) from $\mathrm{CD}^{+}$RCC-Y-TILs after co-culture with autologous tumor cells in $(\mathbf{E})$ a representative $\mathrm{RCC}$ patient $(\mathrm{RCC} 12)$ and $(\mathbf{F})$ a representative melanoma patient. (E) Only $17.5 \%$ of $\mathrm{CD}^{+} \mathrm{CD} 107 \mathrm{a}^{+}$RCC-Y-TILs also produce cytokines whereas (F) $62.1 \%$ of $\mathrm{CD} 8^{+} \mathrm{CD} 107 \mathrm{a}^{+}$ RCC-Y-TILs also produce cytokines.

\section{Figure 4. $\mathrm{CD4}^{+} \mathrm{T}$-cell responses in $\mathrm{RCC}$ and MM.}

The figure shows antitumor CD4 ${ }^{+}$T-cell responses in RCC- $(n=17)$ and MM- $(n=14)$ Y-TILs and REP-TILs after co-culture with autologous fresh tumor digests (FTD) or tumor cell lines (TCLs), treated with IFN $\gamma(\mathrm{TCL}+\mathrm{IFN} \gamma)$ or left untreated, as described in materials and methods. Tumorreactive $\mathrm{T}$ cells are defined as $\mathrm{T}$ cells expressing at least one of the following $\mathrm{T}$-cell functions: TNF, IFN $\gamma$ or CD107a. (A and B) Upper panels: the number/(\%) of patients containing Y-TILs with (dark grey) or without (light grey) $\mathrm{CD} 4^{+} \mathrm{T}$-cell responses against TCLs $+/-$ IFN $\gamma$ is shown in the pie charts. We found no statistically significant difference when comparing Y-TILs co-cultured with untreated TCLs from RCC and MM $(P=0.07)$, whereas a higher percentage of MM-TILs had CD4 ${ }^{+} \mathrm{T}^{-c e l l}$ responses towards TCLs + IFN $\gamma$ compared to RCC-TILs $(P=0.03)$. Lower panels: dots and triangles represent RCC- and MM-TILs respectively; black and grey symbols represent respectively Y-TILs with or without $\mathrm{CD}^{+}$T-cell responses against TCLs $+/$- IFN $\gamma$. Limit of detection was $0.5 \%$. Lines show median values. The magnitude of $\mathrm{CD}^{+} \mathrm{T}$-cell responses in Y-TILs against autologous TCLs treated with IFN $\gamma$ was not statistically significantly lower in RCC compared to MM (only TILs with responses are compared; $P=0.08)$. (C and D) The percentages of tumor-reactive $\mathrm{CD}^{+} \mathrm{Y}-\mathrm{TILs}(\mathbf{C})$ 
and $\mathrm{CD}^{+}$REP-TILs (D) after co-culture with autologous FTDs (light grey bars), untreated TCLs (dark grey bars) or TCLs + IFN $\gamma$ (black bars), in individual RCC patients, are shown. In patients where autologous TCLs were not available, TILs were only tested against FTDs (RCC3, RCC5, RCC8, RCC10 and RCC11). Dotted line: limit of detection (0.5\%). (E) The FACS plots demonstrate cytokine production from representative RCC-Y-TILs after co-culture with autologous tumor cells. 


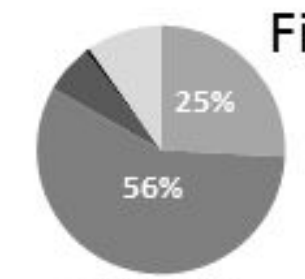

RCC-Y-TIL
$40 \%$

MM-Y-TIL

CD4/CD8 ratio: 2.1

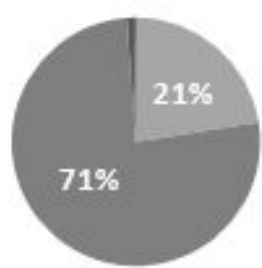

RCC-REP-TIL
- CD8 ${ }^{+} \mathrm{T}$ cells

- CD4+ T cells

CD4-DC8- T cells

- $\mathrm{CD}^{+}{ }^{+} \mathrm{CD} 8^{+} \mathrm{T}$ cells CD3-CD56+ NK cells

B

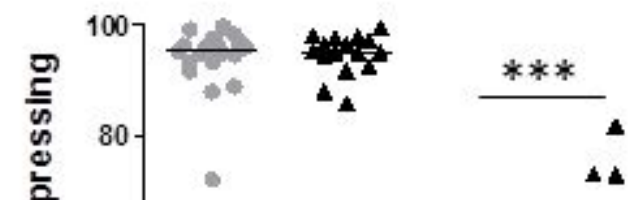

- RCC

CD4/CD8 ratio: 3.6 

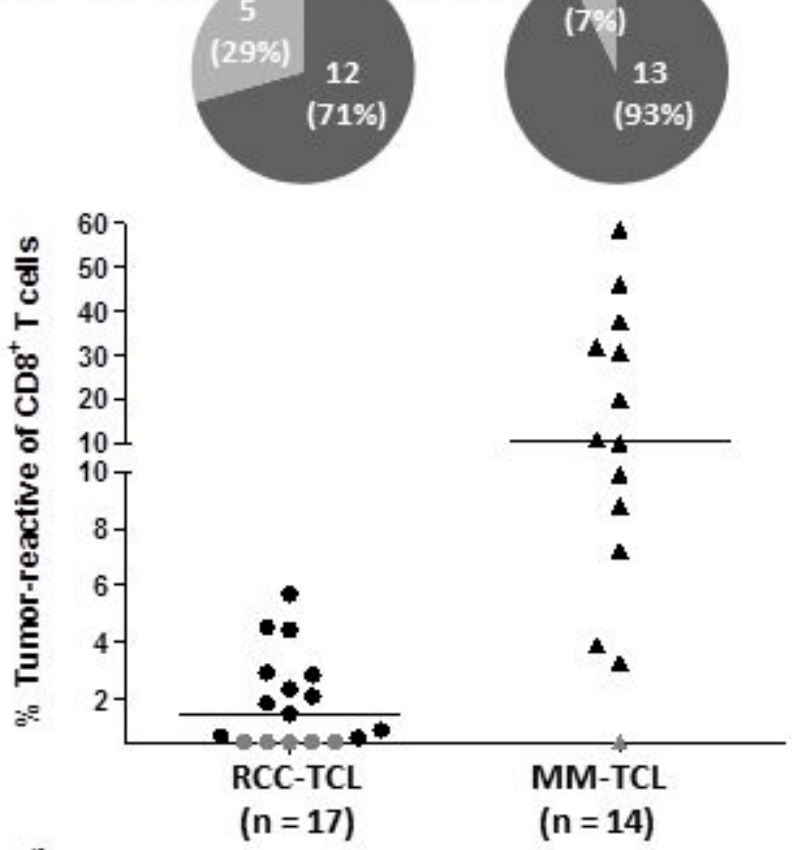

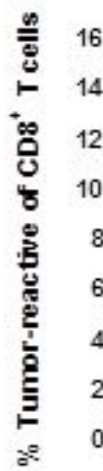

D

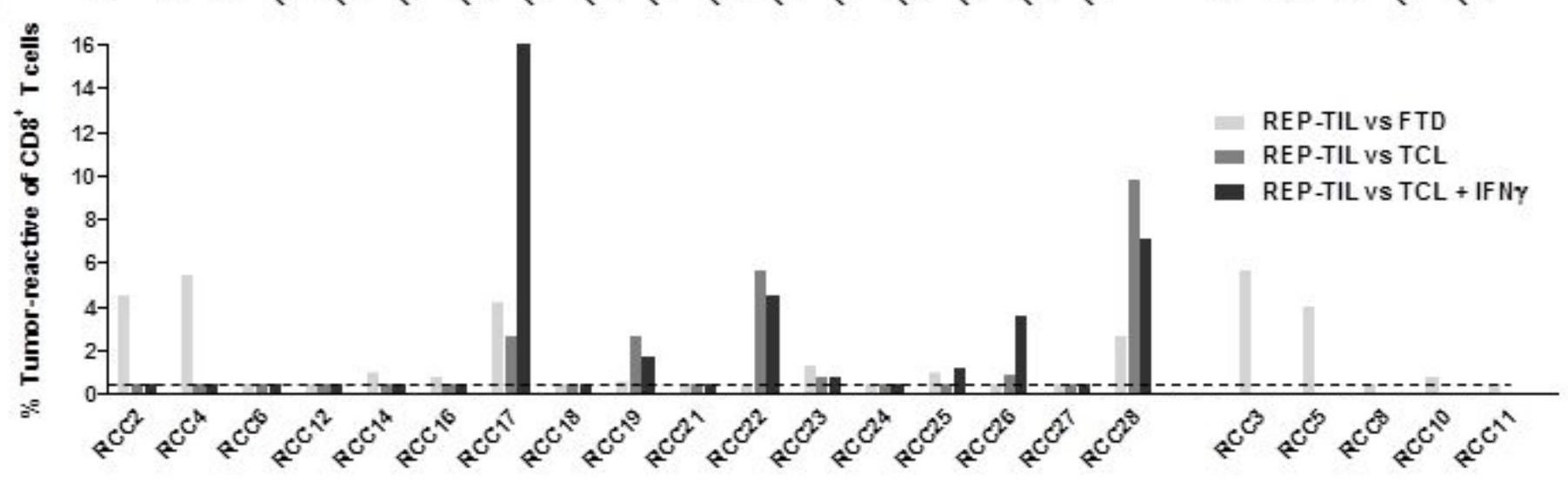

E
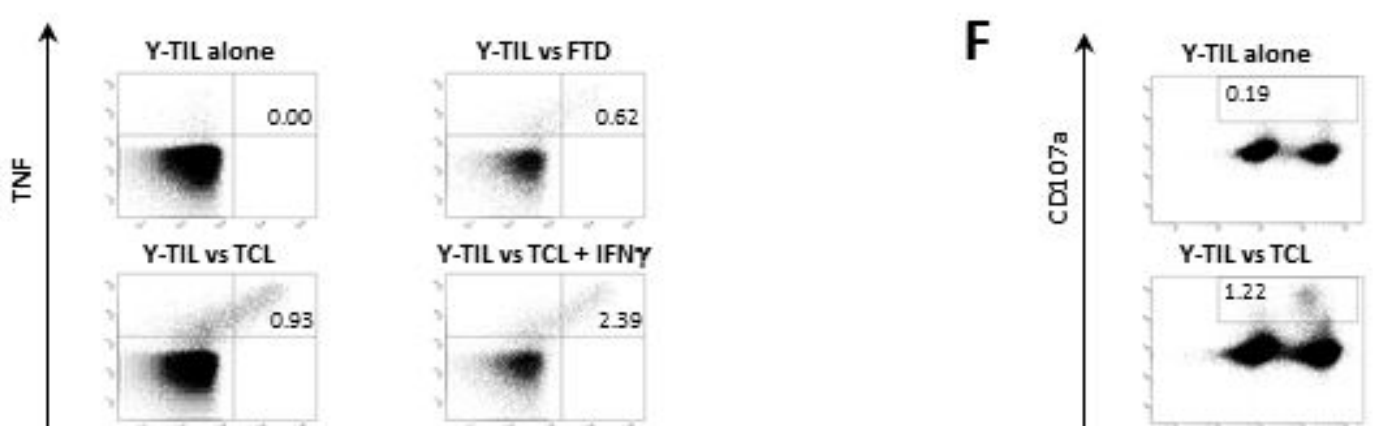

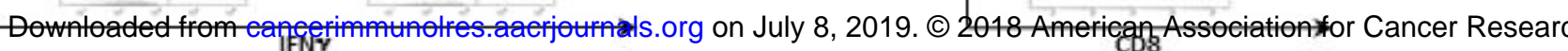

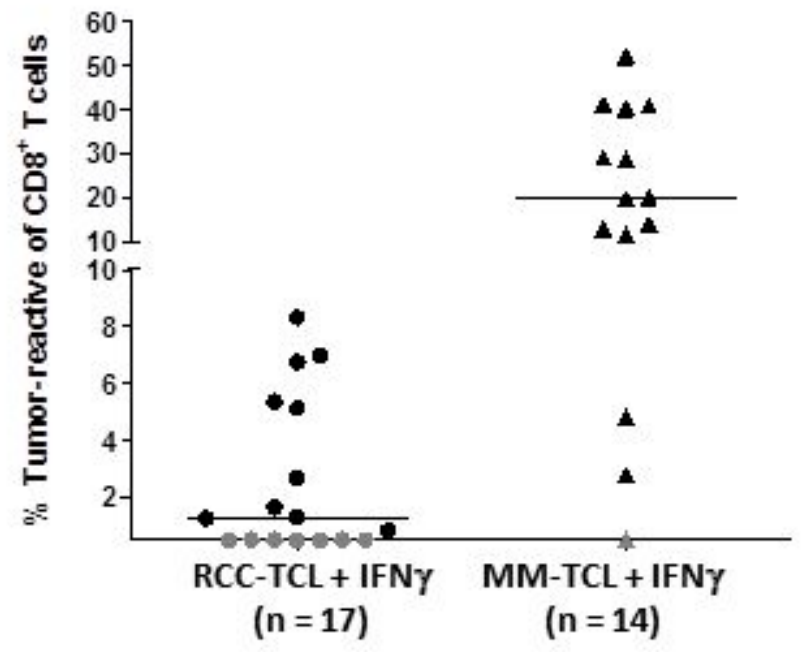

Y-TIL vs FTD

- Y-TIL vs TCL

- Y-TIL vs TCL + IFNy 
A Figure 3

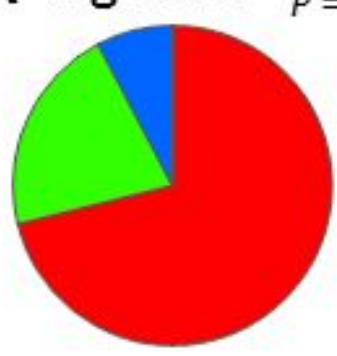

RCC

3 functions

Pie Slice

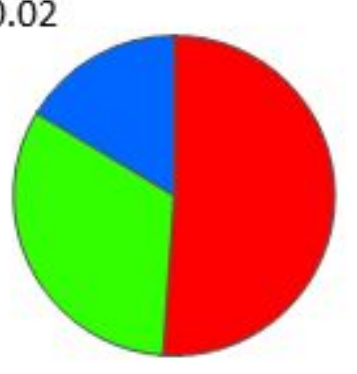

MM
B Pie Chart Arc Legend

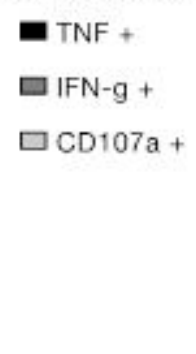

TNF

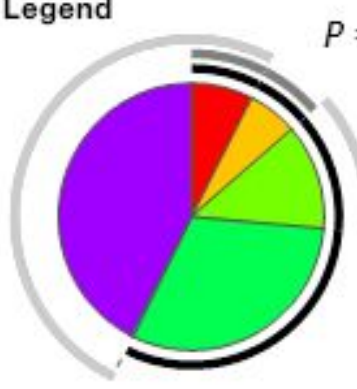

RCC
$=0.01$

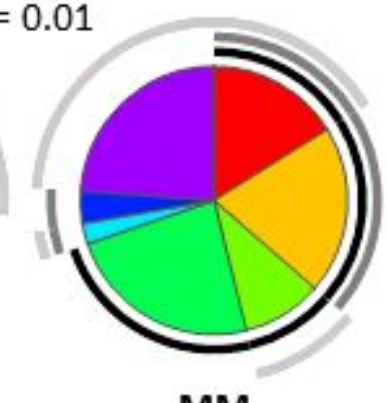

MM
IFN-g

CD107a

Pie Slice

D

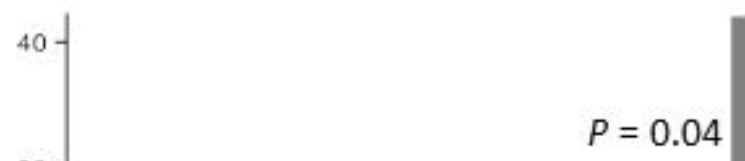

- MM

RCC

30

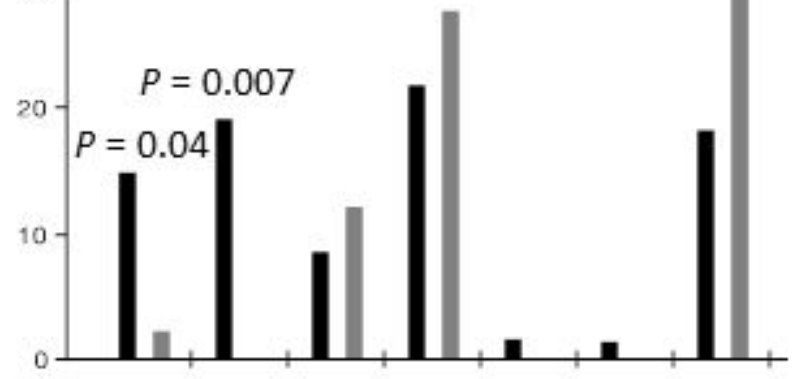

TNF

IFN-g

CD107a

Pie Slice

IFN-g
E

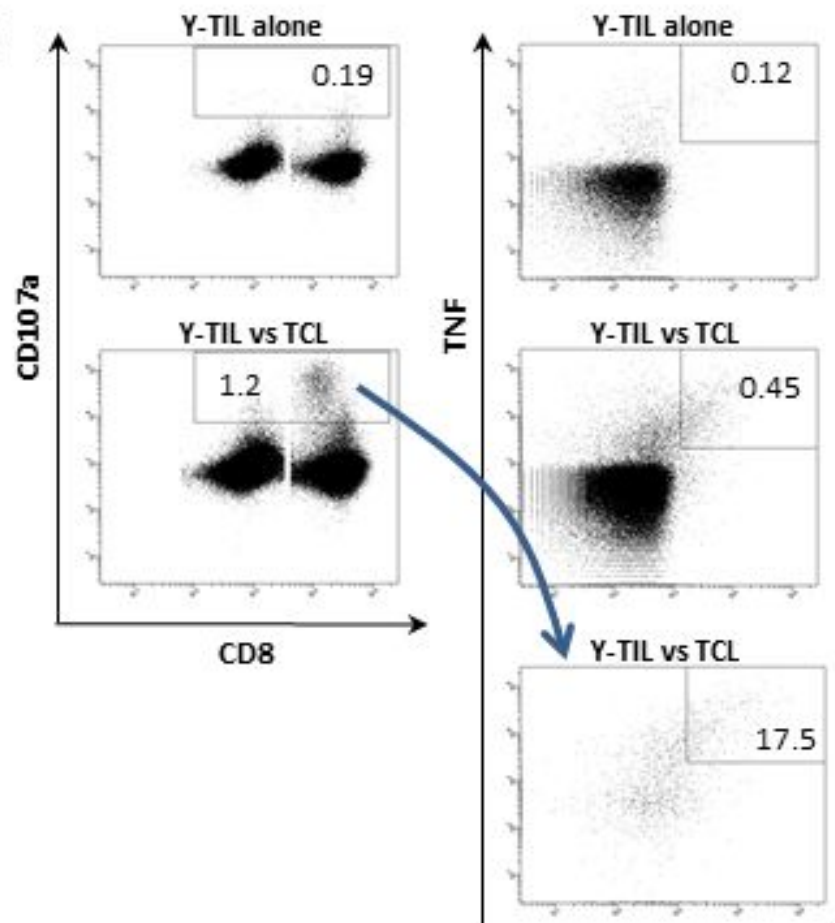

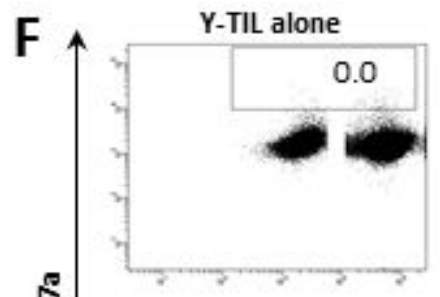

옹

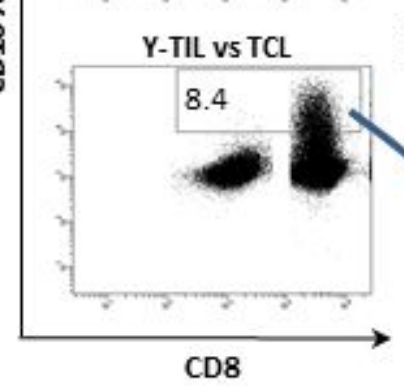

$\stackrel{n}{2}$

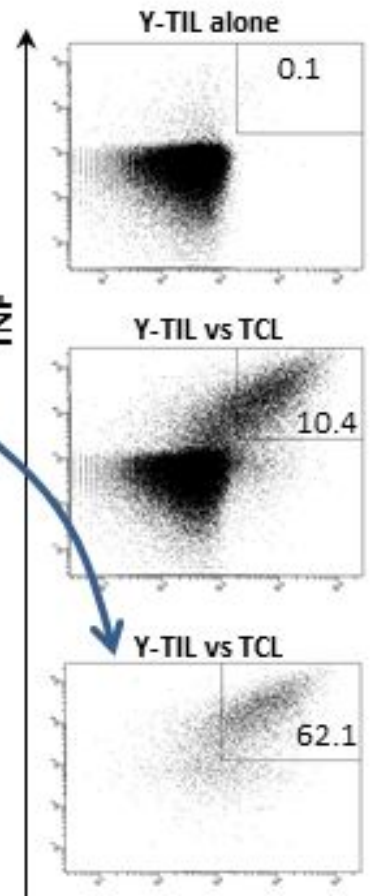

Downloaded from cancerimmunolres aacrjournals.org on July 8, 2019. (c) 2018 American Association for Gancer Researc IFN $\gamma$ IFN $\gamma$ 

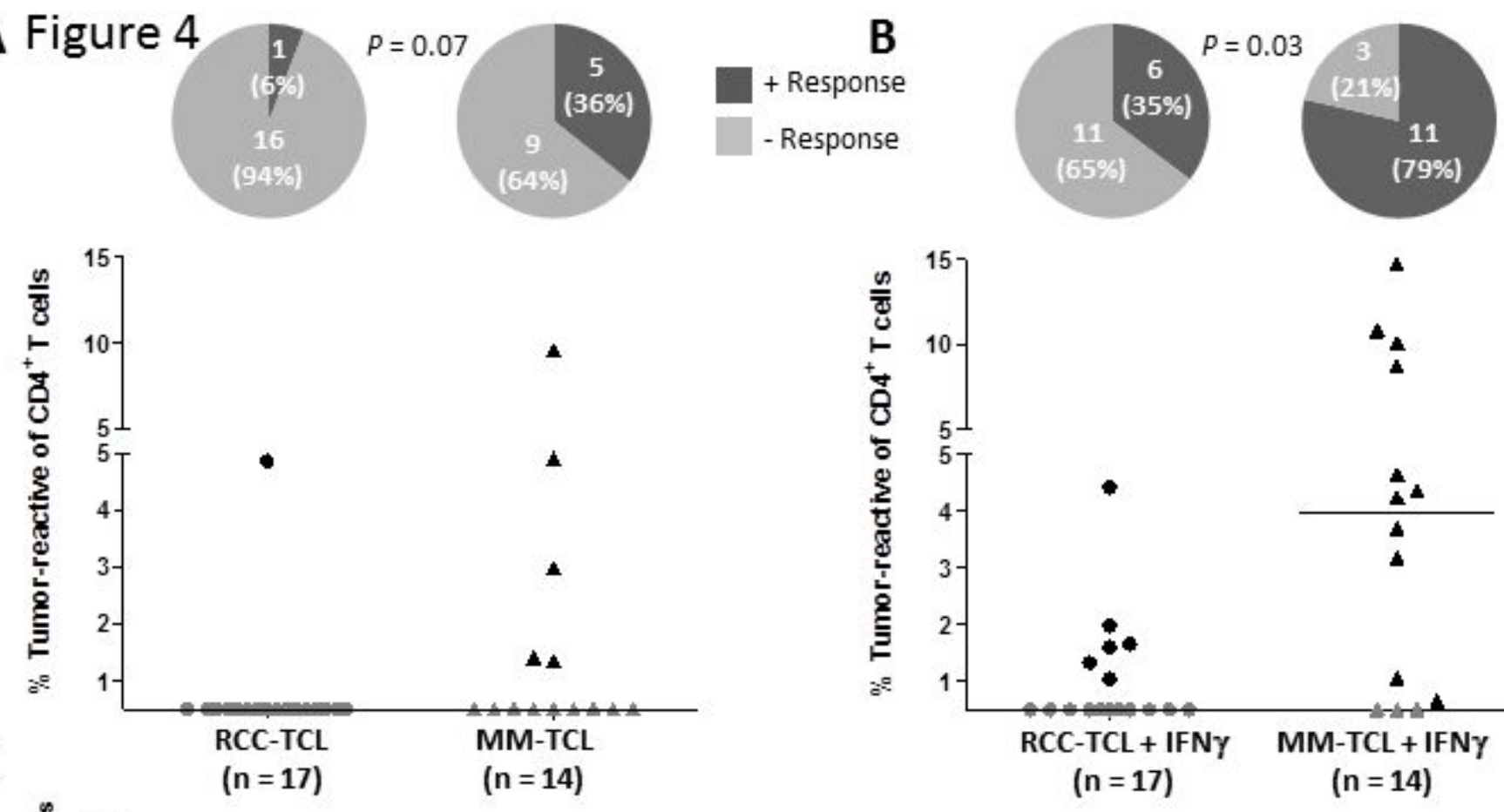

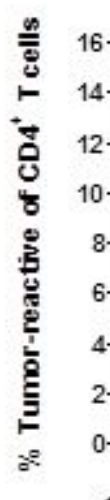

D

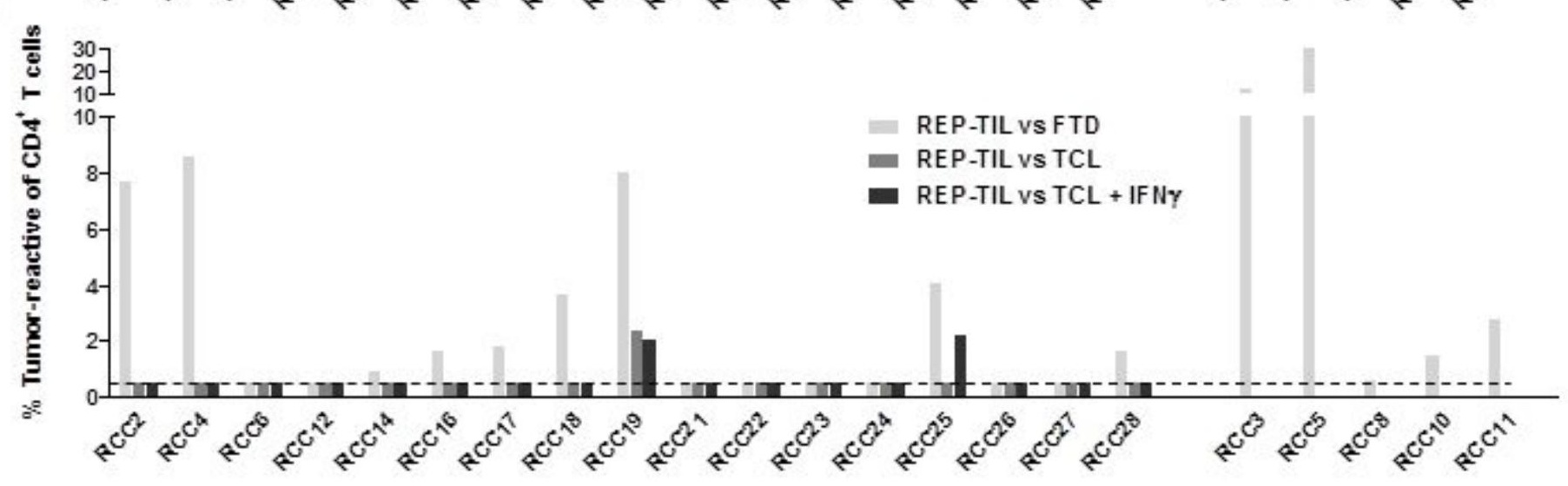

E

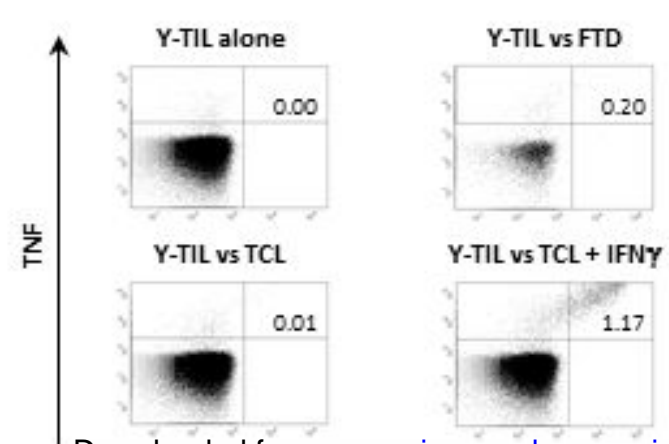

Downloaded from eaneserimmunolres.aaerjournats.org on July 8, 2019. (C) 2018 American Association for Cancer Researc 
AACR

\section{Cancer Immunology Research}

\section{T cell responses in the microenvironment of primary renal cell carcinoma - Implications for adoptive cell therapy}

Rikke Andersen, Marie Christine Wulff Westergaard, Julie Westerlin Kjeldsen, et al.

Cancer Immunol Res Published OnlineFirst January 4, 2018.

\section{Updated version Access the most recent version of this article at: doi:10.1158/2326-6066.CIR-17-0467}

Supplementary Access the most recent supplemental material at:

Material http://cancerimmunolres.aacrjournals.org/content/suppl/2018/02/22/2326-6066.CIR-17-0467.DC1

Author Author manuscripts have been peer reviewed and accepted for publication but have not yet been Manuscript edited.

E-mail alerts Sign up to receive free email-alerts related to this article or journal.

Reprints and To order reprints of this article or to subscribe to the journal, contact the AACR Publications Subscriptions Department at pubs@aacr.org.

Permissions To request permission to re-use all or part of this article, use this link http://cancerimmunolres.aacrjournals.org/content/early/2018/01/04/2326-6066.CIR-17-0467. Click on "Request Permissions" which will take you to the Copyright Clearance Center's (CCC) Rightslink site. 